Prepared in cooperation with the Colorado Water Conservation Board and the Upper Big Sandy Groundwater Management District

\title{
Water-Budget Analysis of the Upper Big Sandy Designated Groundwater Basin Alluvial Aquifer, Elbert, El Paso, and Lincoln Counties, Colorado, 2016
}

Scientific Investigations Report 2019-5049 



\section{Water-Budget Analysis of the Upper Big Sandy Designated Groundwater Basin Alluvial Aquifer, Elbert, El Paso, and Lincoln Counties, Colorado, 2016}

By Michael S. Kohn, Jeannette H. Oden, and L.R. Arnold

Prepared in cooperation with the Colorado Water Conservation Board and the Upper Big Sandy Groundwater Management District

Scientific Investigations Report 2019-5049 


\title{
U.S. Department of the Interior \\ DAVID BERNHARDT, Secretary
}

\author{
U.S. Geological Survey \\ James F. Reilly II, Director
}

U.S. Geological Survey, Reston, Virginia: 2019

For more information on the USGS - the Federal source for science about the Earth, its natural and living resources, natural hazards, and the environment-visit https://www.usgs.gov or call 1-888-ASK-USGS.

For an overview of USGS information products, including maps, imagery, and publications,

visit https://store.usgs.gov.

Any use of trade, firm, or product names is for descriptive purposes only and does not imply endorsement by the U.S. Government.

Although this information product, for the most part, is in the public domain, it also may contain copyrighted materials as noted in the text. Permission to reproduce copyrighted items must be secured from the copyright owner.

Suggested citation:

Kohn, M.S., Oden, J.H., and Arnold, L.R., 2019, Water-budget analysis of the Upper Big Sandy Designated Groundwater Basin alluvial aquifer, Elbert, El Paso, and Lincoln Counties, Colorado, 2016: U.S. Geological Survey Scientific Investigations Report 2019-5049, 25 p., https://dx.doi.org/10.3133/sir20195049.

ISSN 2328-0328 (online) 


\section{Acknowledgments}

The authors wish to thank the Colorado Water Conservation Board and the Upper Big Sandy Groundwater Management District for supporting this study. Dave Stone with the city of Limon provided valuable municipal pumping records from several municipalities in the study area. Tara Gross of the U.S. Geological Survey helped produce several of the figures in this report. 


\section{Contents}

Acknowledgments .......................................................................................................................ii

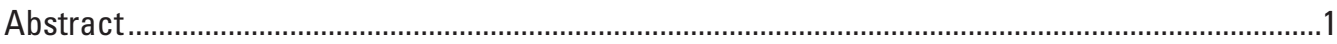

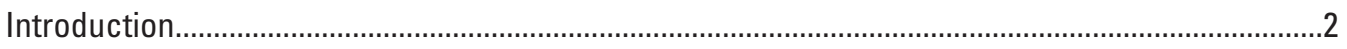

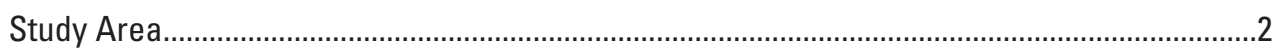

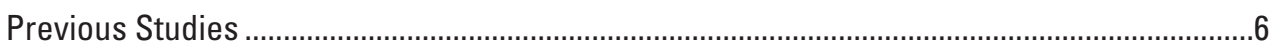

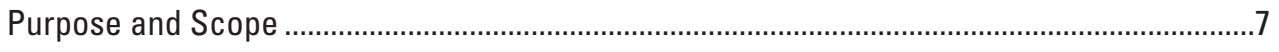

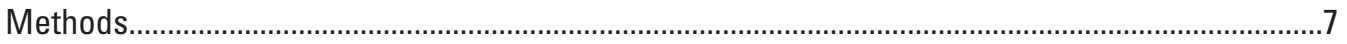

Water-Budget Components within Denver Basin Modeled Area ...............................................

Denver Basin Model Updates.........................................................................................

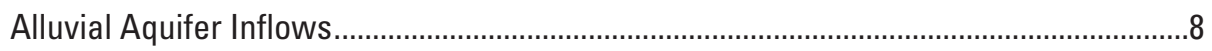

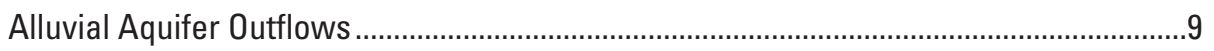

Water-Budget Components within Unmodeled Area ……….....................................................

Alluvial Aquifer Inflows .........................................................................................

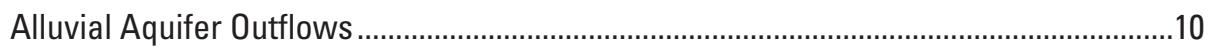

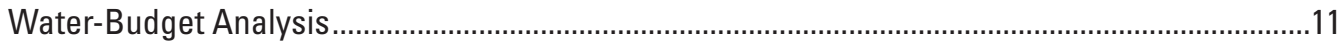

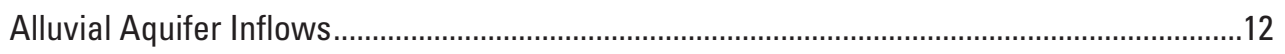

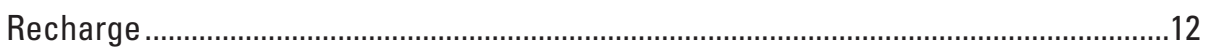

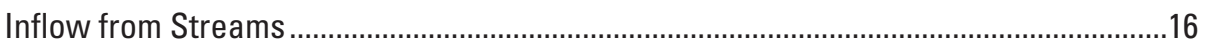

Inflow from Adjacent Alluvial Aquifers ...................................................................16

Inflow from Underlying Bedrock Aquifers ................................................................16

Inflow from Upgradient Modeled Area ...................................................................16

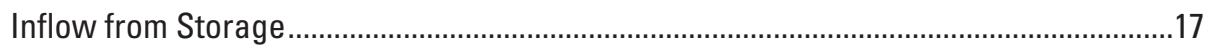

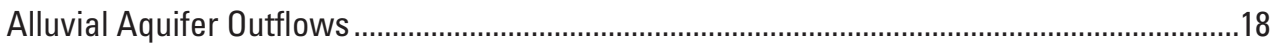

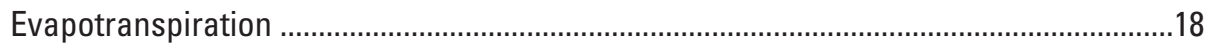

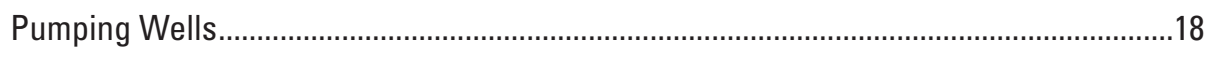

Outflow to Streams ............................................................................................18

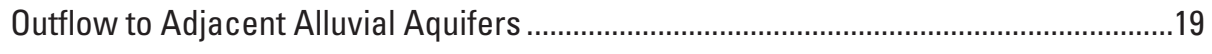

Outflow to Underlying Bedrock Aquifers .....................................................................19

Outflow to Downgradient Areas from the Upper Big Sandy Designated

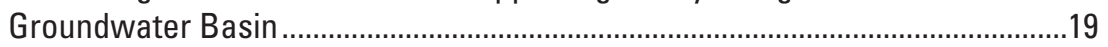

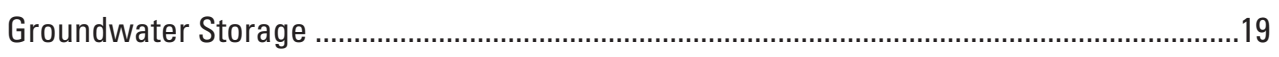

Change in Water-Budget Components Over Time......................................................20

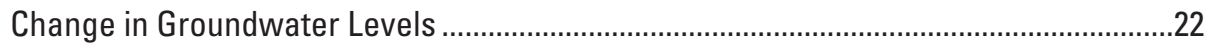

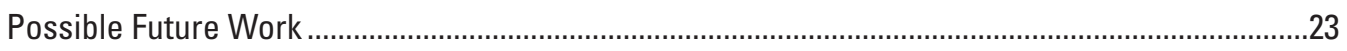

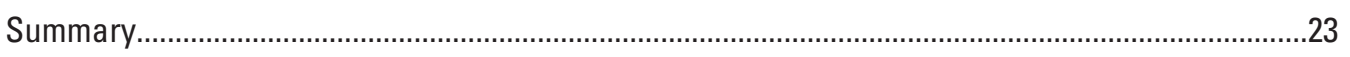

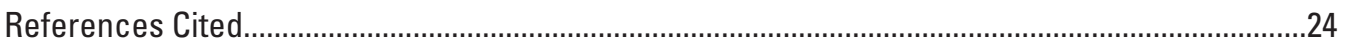




\section{Figures}

1. Map showing location of the Upper Big Sandy Designated Groundwater Basin in eastern Colorado .

2. Map showing location of the Denver Basin aquifer system, Upper Big Sandy Designated Groundwater Basin modeled area, Upper Big Sandy Designated Groundwater Basin alluvial aquifer modeled area, Upper Big Sandy Designated Groundwater Basin unmodeled area, and the Upper Big Sandy Designated Groundwater Basin alluvial aquifer in eastern Colorado. .4

3. Map showing location of extent of Denver Basin aquifers and confining units and Upper Big Sandy Designated Groundwater Basin and lines of hydrogeologic sections $A-A^{\prime}$ and $B-B^{\prime}$ in eastern Colorado...

4. Generalized hydrogeologic sections $A, A-A^{\prime}$, west to east, and $B, B-B^{\prime}$, south to north, through the Denver Basin aquifer system

5. Graph showing net increase in new pumping wells and the total number of pumping wells from 2004 through 2016 in the Upper Big Sandy Designated Groundwater Basin in modeled and unmodeled areas in Colorado.....

6. Map showing location of the 1,512 pumping wells operating in the Upper Big Sandy Designated Groundwater Basin in modeled and unmodeled areas in Colorado, 2016

7. Pie chart showing the 2016 Upper Big Sandy Designated Groundwater Basin alluvial aquifer $A$, inflows and $B$, outflows for the modeled area, Colorado ...

8. Pie chart showing the 2016 Upper Big Sandy Designated Groundwater Basin alluvial aquifer $A$, inflows and $B$, outflows for the unmodeled area, Colorado.

9. Pie chart showing the 2016 Upper Big Sandy Designated Groundwater Basin alluvial aquifer net inflows and outflows for the modeled and unmodeled areas combined, Colorado

10. Map showing the spatial distribution of the flow between the bedrock aquifers and the Upper Big Sandy Designated Groundwater Basin alluvial aquifer in Colorado, 2016

11. Graph showing change in flow rates over time between the bedrock aquifers and the Upper Big Sandy Designated Groundwater Basin alluvial aquifer.

12. Graph showing the annual water budget over time for the modeled area of the Upper Big Sandy Designated Groundwater Basin alluvial aquifer in Colorado..

13. Map showing the change in groundwater levels in observation wells in the Upper Big Sandy Designated Groundwater Basin alluvial aquifer, Colorado, from 2003 through 2016 


\section{Tables}

1. Assigned pumpage rates for wells in the Upper Big Sandy Designated Groundwater Basin, Colorado

2. Net Increase in pumping wells from 2004 through 2016 in the Upper Big Sandy Designated Groundwater Basin in modeled and unmodeled areas in Colorado

3. Water budget for the Upper Big Sandy Designated Groundwater Basin, modeled and unmodeled areas, in Colorado, 2016

4. Net flow between the Upper Big Sandy Designated Groundwater Basin alluvial aquifer and adjacent bedrock aquifer units in Colorado

5. Pumpage volumes for the 11 Town of Limon, Colorado, municipal pumping wells for 2016

6. Total pumpage volume estimates for pumping wells in the unmodeled area in the Upper Big Sandy Designated Groundwater Basin, Colorado

\section{Conversion Factors}

U.S. customary units to International System of Units

\begin{tabular}{|c|c|c|}
\hline Multiply & By & To obtain \\
\hline \multicolumn{3}{|c|}{ Length } \\
\hline inch (in.) & 2.54 & centimeter $(\mathrm{cm})$ \\
\hline inch (in.) & 25.4 & millimeter $(\mathrm{mm})$ \\
\hline foot $(\mathrm{ft})$ & 0.3048 & meter $(\mathrm{m})$ \\
\hline mile (mi) & 1.609 & kilometer $(\mathrm{km})$ \\
\hline \multicolumn{3}{|c|}{ Area } \\
\hline acre & 43,560 & square feet $\left(\mathrm{ft}^{2}\right)$ \\
\hline \multicolumn{3}{|c|}{ Volume } \\
\hline acre-foot (acre-ft) & 43,560 & cubic feet $\left(\mathrm{ft}^{3}\right)$ \\
\hline \multicolumn{3}{|c|}{ Flow rate } \\
\hline acre-foot per year (acre-ft/yr) & 119.342 & cubic feet per day $\left(\mathrm{ft}^{3} / \mathrm{d}\right)$ \\
\hline
\end{tabular}

\section{Datum}

Vertical coordinate information is referenced to the [insert datum name (and abbreviation) here; for example, North American Vertical Datum of 1988 (NAVD 88)].

Horizontal coordinate information is referenced to the [insert datum name (and abbreviation) here; for example, North American Datum of 1983 (NAD 83)].

\section{Abbreviations}

CGWC Colorado Ground Water Commission

UBSDGB Upper Big Sandy Designated Groundwater Basin

USGS U.S. Geological Survey 


\title{
Water-Budget Analysis of the Upper Big Sandy Designated Groundwater Basin Alluvial Aquifer, Elbert, El Paso, and Lincoln Counties, Colorado, 2016
}

\author{
By Michael S. Kohn, Jeannette H. Oden, and L.R. Arnold
}

\begin{abstract}
The U.S. Geological Survey in cooperation with the Colorado Water Conservation Board and the Upper Big Sandy Groundwater Management District carried out a study in 2016 to evaluate potential groundwater storage changes within the Upper Big Sandy Designated Groundwater Basin (UBSDGB) alluvial aquifer, including groundwater flow between the UBSDGB alluvial aquifer and the Denver Basin bedrock aquifers. The UBSDGB alluvial aquifer is located along the ephemeral Big Sandy Creek on the east-central edge of the Denver Basin aquifer system and covers an area of about 66,560 acres within the UBSDGB. The UBSDGB alluvial aquifer consists of unconsolidated Quaternary sand and gravel deposits that contain an unconfined (water table) groundwater system. The western three-fourths of the UBSDGB alluvial aquifer overlies the Tertiary and Cretaceous bedrock formations that compose the Denver Basin aquifer system. The updated water budget for the UBSDGB alluvial aquifer, including annual change in groundwater storage in 2016, was determined by combining water-budget information from an existing Denver Basin model for about three-fourths of the study area with best estimates for the major water-budget components for the area outside the Denver Basin aquifer system. The western part of the UBSDGB was included in the Denver Basin model (modeled area), whereas the eastern part of the UBSDGB was not included in the Denver Basin model (unmodeled area). The water-budget components were first estimated for the modeled area using outputs from the Denver Basin model, which uses the modular finite-difference groundwater flow computer model MODFLOW-2000 with 1-mile grid cells. For this study, the Denver Basin model was updated with additional data from 2004 through 2016 to generate current (2016) estimates of water consumption in the UBSDGB alluvial aquifer. A basin-specific water budget for the UBSDGB alluvial aquifer from the Denver Basin model was computed using a modeling tool called ZONEBUDGET. The modeled area groundwater budget, along with previous studies, was used to estimate a groundwater budget for the unmodeled area, and results for the modeled and unmodeled areas were combined for an overall water-budget estimate for the entire UBSDGB alluvial aquifer.
\end{abstract}

The net groundwater flow into the basin from adjacent alluvial aquifers was positive with flow entering the UBSDGB alluvial aquifer. Combining the total inflow from adjacent alluvial and the total outflow to adjacent alluvial aquifers resulted in a net flow from adjacent alluvial aquifers to UBSDGB alluvial aquifer of 5,125 acre-feet (ac-ft) in 2016. The net flow between the underlying bedrock aquifers and the UBSDGB alluvial aquifer was positive with flow entering the UBSDGB alluvial aquifer from the bedrock aquifers. The net flow from the bedrock aquifers to the UBSDGB alluvial aquifer was $347 \mathrm{ac}-\mathrm{ft}$ in 2016. Net recharge (precipitation and irrigation return flows minus evaporation) into the UBSDGB alluvial aquifer was negative with groundwater being removed from the UBSDGB alluvial aquifer over the total area of the basin. Combining the total inflow from recharge to the UBSDGB alluvial aquifer of $11,153 \mathrm{ac}-\mathrm{ft}$ in 2016 and the total evapotranspiration of $-11,656 \mathrm{ac}-\mathrm{ft}$ from the UBSDGB alluvial aquifer in 2016 resulted in a net recharge from UBSDGB alluvial aquifer of $-503 \mathrm{ac}-\mathrm{ft}$ in 2016 . Combining the modeled and unmodeled well pumping resulted in a total well pumping volume of $-3,735 \mathrm{ac}-\mathrm{ft}$ in 2016 from the UBSDGB alluvial aquifer. The net groundwater flow to the stream network in the basin was negative with flow discharging from the UBSDGB alluvial aquifer into streams. Combining the total inflow from streams and the total outflow to streams for the UBSDGB alluvial aquifer resulted in $-1,032 \mathrm{ac}-\mathrm{ft}$ in 2016 that was lost to the stream network in the UBSDGB. The net groundwater flow out of the UBSDGB was negative with flow leaving the UBSDGB alluvial aquifer. Combining the total area inflow to the basin from upgradient areas and the total area outflow from the basin for the UBSDGB alluvial aquifer resulted in a net flow out of the basin of $-2,300 \mathrm{ac}-\mathrm{ft}$. In the annual groundwater budget for 2016, groundwater storage in the UBSDGB alluvial aquifer system was removed because annual groundwater outflows from storage exceeded groundwater inflows to storage; in other words, water was removed from storage to balance the annual water budget. Combining the net flow from storage for the modeled area of $73 \mathrm{ac}-\mathrm{ft}$ and the inflow from storage for the unmodeled area of 2,025 ac-ft resulted in a net positive flow from storage of the UBSDGB alluvial aquifer of 2,098 ac-ft. 
Increased pumping since 1958 in the Denver and upper Arapahoe aquifers, not necessarily in the UBSDGB, has caused a change in flow from bedrock units, which were minor or non-contributors of inflow to the UBSDGB alluvial aquifer, to receiving outflow from the UBSDGB alluvial aquifer. Since 2000, aquifer storage has been an inflow component of the water budget, which means that outflow from the modeled area exceeded inflow for the UBSDGB alluvial aquifer. Increased recharge from wetter than average years could replenish the UBSDGB alluvial aquifer. From 2003 through 2016, 13 of the 25 observation wells completed in the UBSDGB alluvial aquifer had a decline in the groundwaterlevel elevation with an average decline of -2.21 feet, and 12 of the 25 observation wells had an increase in the groundwater-level elevation with an average increase of 1.54 feet. In general, wells at the eastern and western edges of the UBSDGB showed an increase in groundwater-level elevation that appears related to areas of groundwater discharge from the lower Dawson and Laramie-Fox Hills bedrock aquifers to the UBSDGB alluvial aquifer. The remaining wells exhibited water-level declines. Future work could include the development of a basin-specific model to serve as a basin management tool for modeling changes in groundwater levels and storage under various future groundwater recharge and withdrawal scenarios.

\section{Introduction}

The U.S. Geological Survey (USGS) in cooperation with the Colorado Water Conservation Board and the Upper Big Sandy Groundwater Management District carried out a study in 2016 to evaluate potential changes to groundwater storage within the Upper Big Sandy Designated Groundwater Basin (UBSDGB) alluvial aquifer. The UBSDGB is in the Arkansas River Basin in parts of El Paso, Elbert, and Lincoln Counties and is one of eight Designated Groundwater Basins in eastern Colorado (fig. 1). Designated Groundwater Basins are areas in the eastern plains of Colorado with very little surface water where users rely primarily on groundwater as their source of water supply (Colorado Division of Water Resources, 2017a). The Colorado Ground Water Commission (CGWC) is a regulatory and an adjudicatory body authorized by the State of Colorado General Assembly to manage and control groundwater resources within eight Designated Ground Water Basins in eastern Colorado. (Colorado Division of Water Resources, 2017a). Designated Groundwater Basins are underlain by unconfined, alluvial sand and gravel aquifers that receive limited recharge in the semi-arid climate, so understanding the hydrogeology of these basins and quantifying the groundwater budget are important for informing the effective management of these groundwater resources.

The Upper Big Sandy Groundwater Management District has administrative authority to manage the withdrawal and use of designated groundwater within the UBSDGB. The Upper Big Sandy Groundwater Management
District was formed on October 22, 1976, by the CGWC. The rules, regulations, and guidelines adopted by the Upper Big Sandy Groundwater Management District are intended to ensure that groundwater in the UBSDGB is put to beneficial use within the UBSDGB on a sustainable basis and in a manner that does not injure prior appropriations of groundwater (Upper Big Sandy Groundwater Management District, 2011). Previous investigations (Martin and Wood Water Consultants, Inc., 2009; Paschke, 2011) indicate that groundwater storage in the UBSDGB alluvial aquifer relies on precipitation and irrigation return flow for recharge and thus can be depleted in dry years. Because of increased pumping from the UBSDGB alluvial aquifer since 1940 (Graham and VanSlyke, 2004), the Upper Big Sandy Groundwater Management District is concerned with potentially declining groundwater levels and thus available groundwater in storage for the UBSDGB alluvial aquifer. The current study quantified a water budget for, and water availability in, the UBSDGB alluvial aquifer, including groundwater flow between the UBSDGB alluvial aquifer and the Denver Basin bedrock aquifers and annual change in groundwater storage in 2016, and provided information for water-resource management of the alluvial aquifer within the UBSDGB. An updated water budget for the UBSDGB alluvial aquifer improves the understanding of the potential effects of urbanization and climate on the future groundwater aquifer storage within the UBSDGB and thus the water supply for agriculture, municipal, domestic, and commercial uses.

\section{Study Area}

The UBSDGB covers an area of 282,170 acres in parts of El Paso, Elbert, and Lincoln Counties (fig. 1). The towns within the UBSDGB include Calhan, Ramah, Simla, Matheson, and Limon (fig. 1). The western extent of the UBSDGB begins at the headwaters of the Big Sandy Creek and covers land on either side of the creek to just east of Limon. Big Sandy Creek is ephemeral and flows generally to the northeast until the Big Bend area where the creek turns to the southeast (fig. 1). This part of Colorado is generally level to rolling prairie broken by occasional hills and bluffs (Doesken and others, 2003).

The climate is semiarid continental with an average annual precipitation of 11-18 inches (Robson, 1987). Humidity is generally quite low (favoring rapid evaporation), rain and snow are infrequent, winds are moderate to high, and the daily and seasonal ranges in temperature are large (Doesken and others, 2003). July average high temperatures are 80-90 degrees Fahrenheit $\left({ }^{\circ} \mathrm{F}\right)$, and the January average low temperatures are $10-12^{\circ} \mathrm{F}$ (Robson, 1987). The wettest time of year over the eastern plains is April through early September. Localized rains from intense thunderstorms pose the greatest threat of flash flooding (Doesken and others, 2003). Precipitation is an important source of water for direct use (irrigation or municipal supply) and as recharge to aquifers (Robson, 1987). 


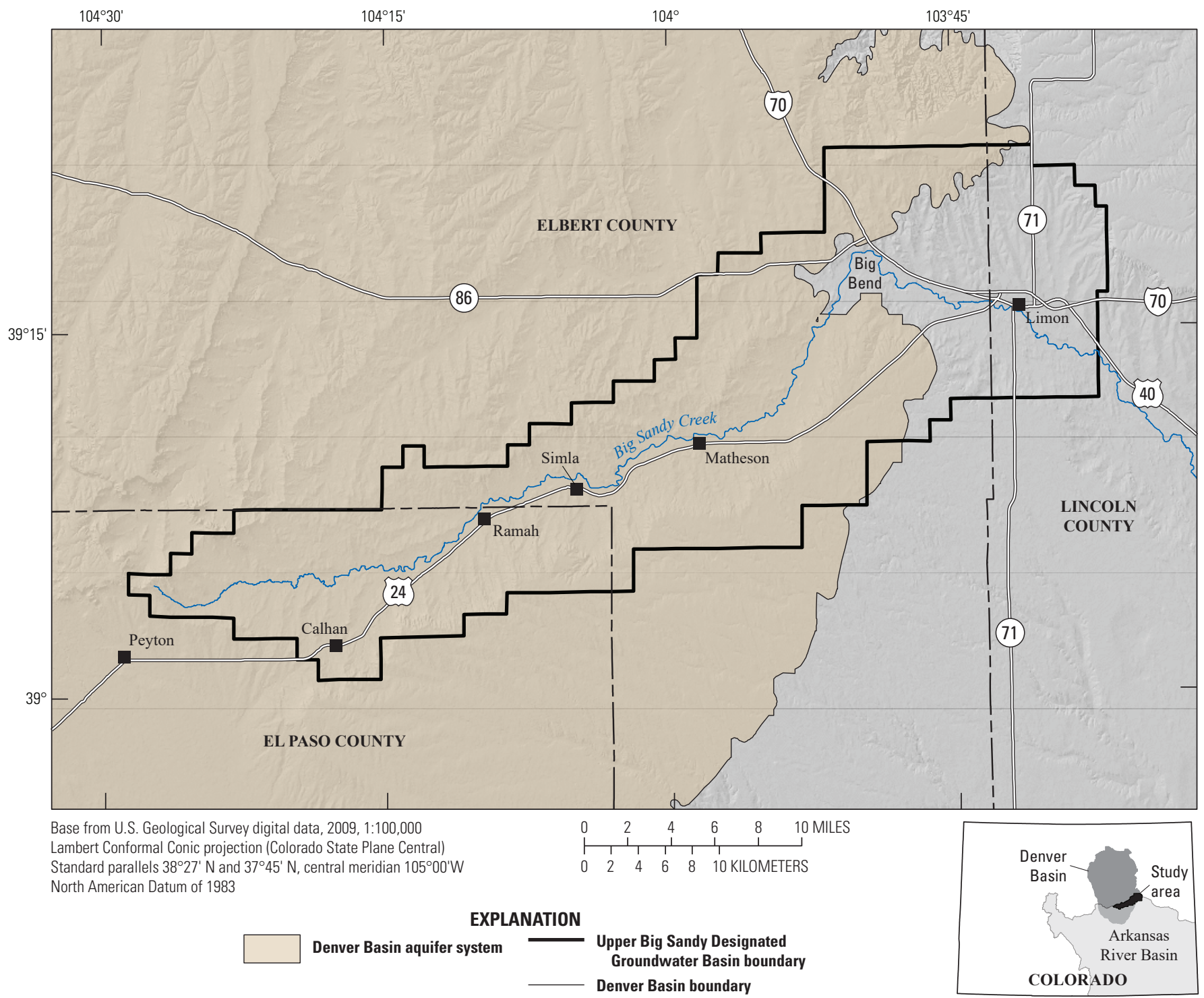

Figure 1. Location of the Upper Big Sandy Designated Groundwater Basin in eastern Colorado.

The UBSDGB alluvial aquifer is located along Big Sandy Creek on the east-central edge of the Denver Basin aquifer system and covers an area of about 66,560 acres within the UBSDGB (fig. 2). The UBSDGB alluvial aquifer consists of unconsolidated Quaternary sand and gravel deposits that contain an unconfined (water table) groundwater system. The base of the aquifer slopes southeast away from the Palmer Divide (fig. 3; Paschke, 2011). Depth to water below land surface in the UBSDGB alluvial aquifer ranges from 6 to 51 feet (Colorado Division of Water Resources, 2017b). Alluvial aquifers are used primarily as a source of irrigation supply, which is the largest water use in the area (Robson, 1987). For the Denver Basin aquifer system, most (about 80 percent) of the water moving in and out of the bedrock aquifers moves through near-surface parts of the system, including the alluvial aquifers; about 62 percent of the water pumped from wells in the Denver Basin aquifer system is from alluvial aquifers (Paschke, 2011).
The western three-fourths of the UBSDGB alluvial aquifer overlies Tertiary and Cretaceous bedrock formations that compose the Denver Basin aquifer system (fig. 3). From oldest to youngest, the four primary units of the Denver Basin aquifer system are the Laramie-Fox Hills aquifer, the Arapahoe aquifer, the Denver aquifer, and the Dawson aquifer (Robson, 1987) (fig. 4). The Denver Basin aquifer system was simulated as a 12-layer system (Paschke, 2011). Starting with the uppermost layer, the layers include (1) alluvial aquifers, (2) upper Dawson aquifer, (3) Dawson confining unit, (4) lower Dawson aquifer, (5) Denver upper confining unit, (6) Denver aquifer, (7) Denver lower confining unit, (8) upper Arapahoe aquifer, (9) Arapahoe confining unit, (10) lower Arapahoe aquifer, (11) Laramie confining unit, and (12) Laramie-Fox Hills aquifer (figs. 3, 4). The five intervening confining units are represented by the same color in figure 3. The lower Dawson, Denver, upper Arapahoe, 
lower Arapahoe, and Laramie-Fox Hills aquifers are present beneath the UBSDGB; the Dawson confining unit and upper Dawson aquifer are not present in the UBSDGB (fig. 3). The eastern one-fourth of the UBSDGB is outside the area of the Denver Basin aquifer system and is underlain by the Pierre Shale (figs. 3, 4), which is generally considered the basal confining unit of the Denver Basin aquifer system (Paschke, 2011). In the eastern part of the study area, the bedrock aquifers of the Denver Basin aquifer system were removed by erosion and are not present. Because of its position with respect to the Denver Basin aquifer system (fig. 2), the western part (329 square miles $\left[\mathrm{mi}^{2}\right]$ ) of the UBSDGB was included in the Denver Basin model (modeled area), whereas the eastern part $\left(111 \mathrm{mi}^{2}\right)$ of the UBSDGB was not included in the Denver Basin model (unmodeled area).

Agriculture is the main economic driver in Elbert County. This county is a top producer of cattle and wheat; $1,043,135$ acres of land are in farms, of which approximately 80 percent was pastureland in 2012 (U.S. Department of Agriculture, 2012a). El Paso County also has a robust agricultural economy based on ranching and farming primarily in the eastern part of the county. Farms account for 648,916 acres of land in El Paso County, of which about 90 percent was pastureland in 2012 (U.S. Department of Agriculture, 2012b). The

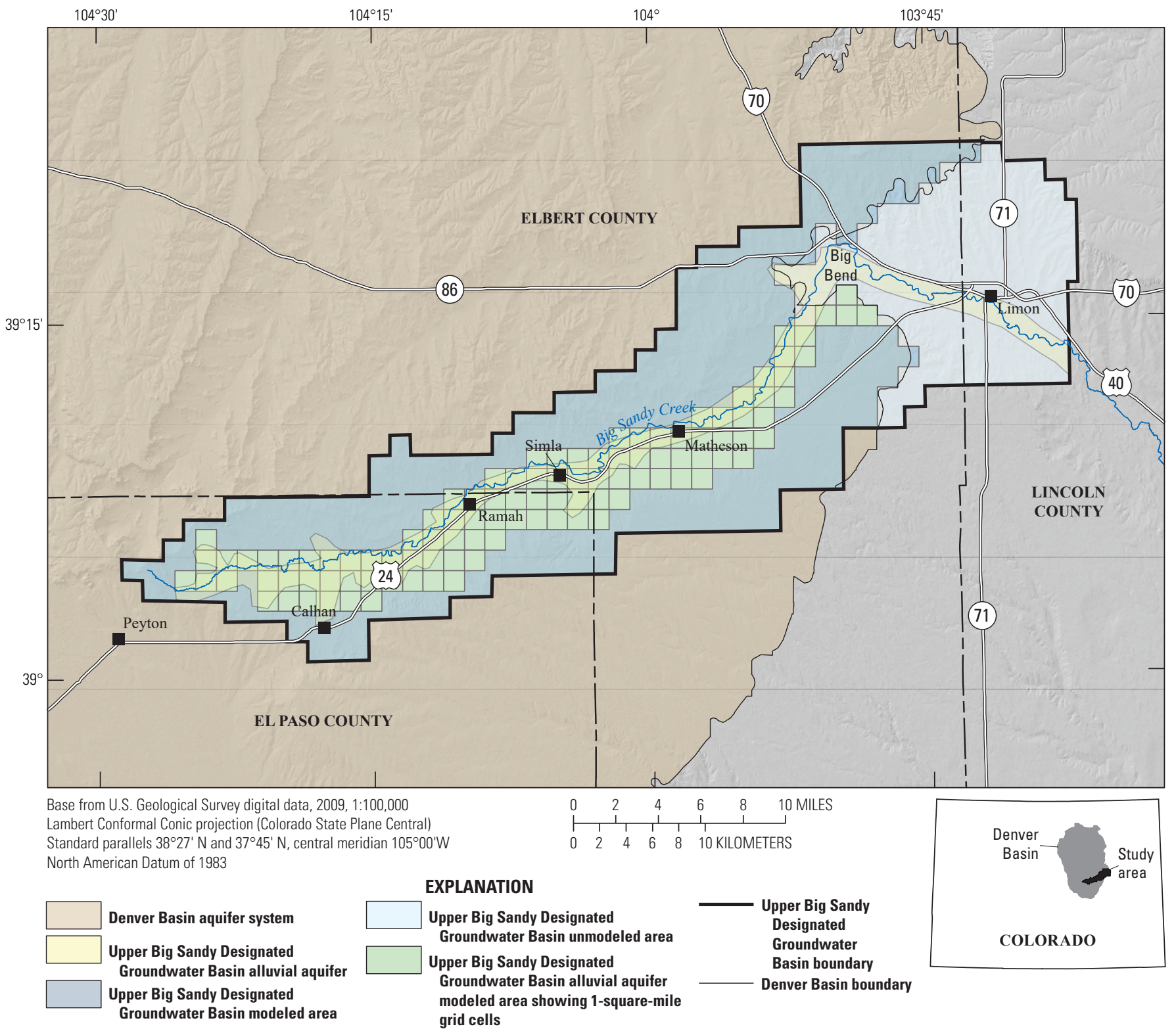

Figure 2. Location of the Denver Basin aquifer system, Upper Big Sandy Designated Groundwater Basin modeled area, Upper Big Sandy Designated Groundwater Basin alluvial aquifer modeled area, Upper Big Sandy Designated Groundwater Basin unmodeled area, and the Upper Big Sandy Designated Groundwater Basin alluvial aquifer in eastern Colorado. 


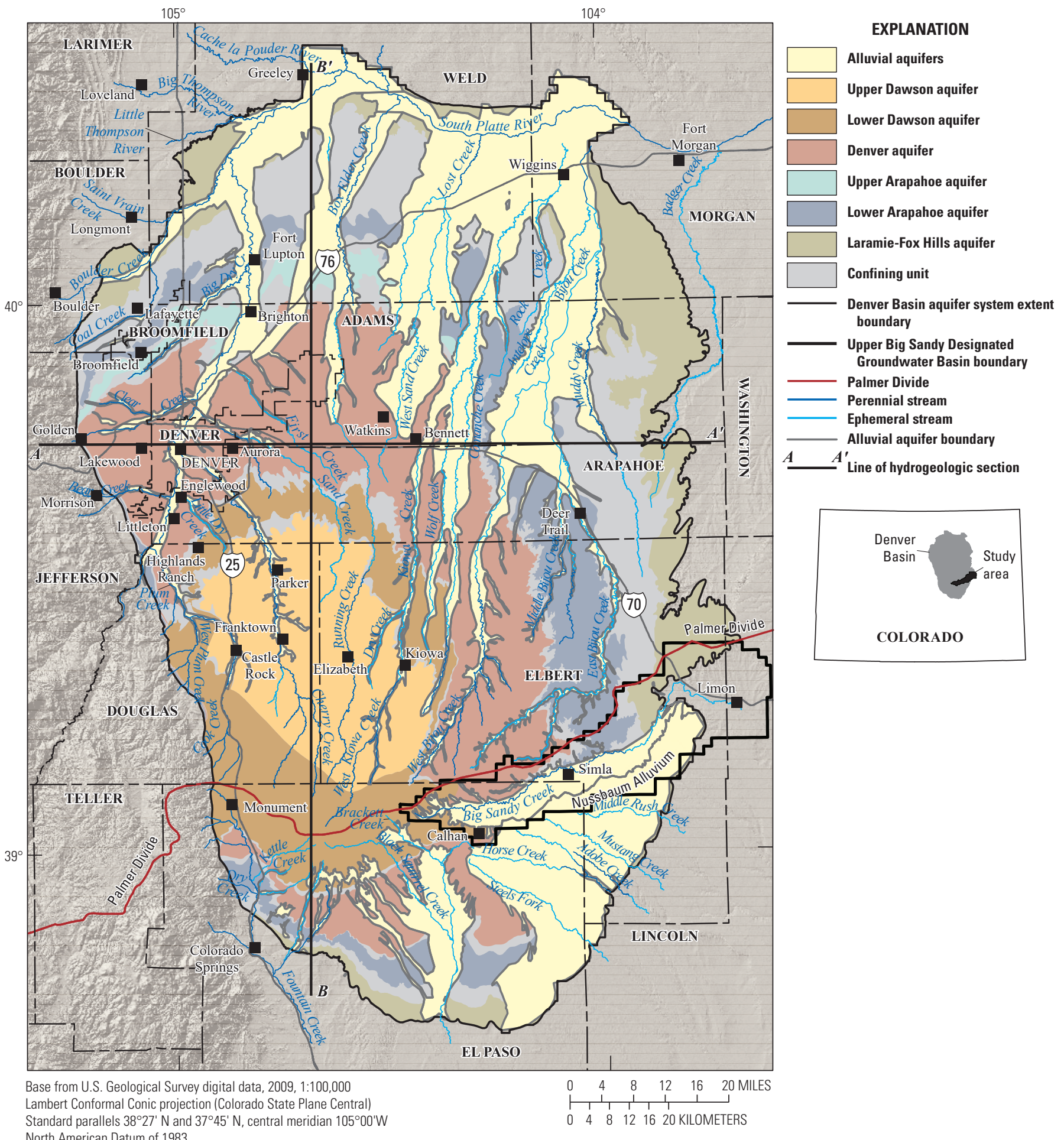

North American Datum of 1983

Figure 3. Location of extent of Denver Basin aquifers and confining units and Upper Big Sandy Designated Groundwater Basin and lines of hydrogeologic sections $A-A^{\prime}$ and $B-B^{\prime}$ (shown in figure 4 ) in eastern Colorado. 

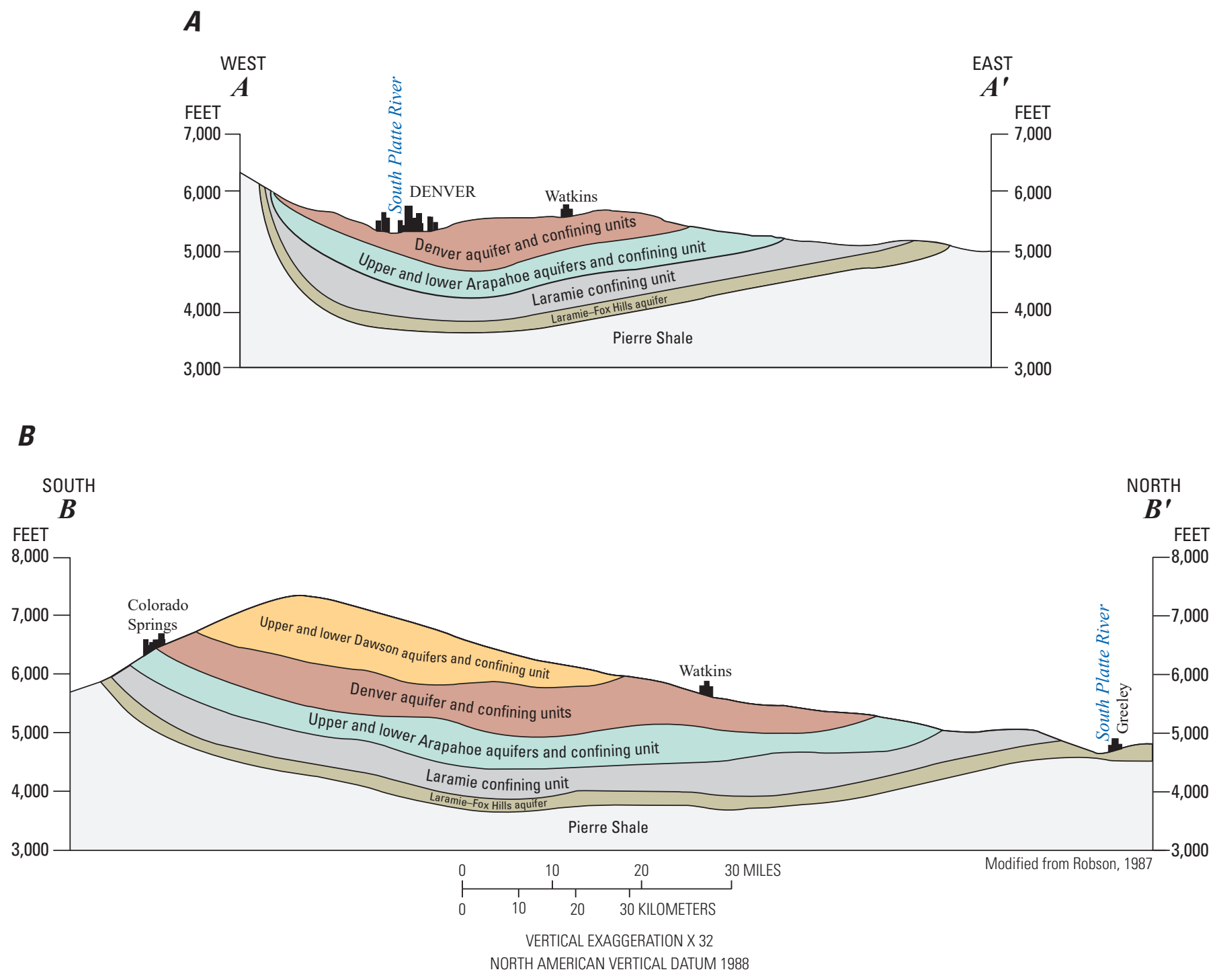

Figure 4. Generalized hydrogeologic sections $A, A-A^{\prime}$, west to east, and $B, B-B^{\prime}$, south to north, through the Denver Basin aquifer system. See figure 3 for cross section locations.

UBSDGB extends into Lincoln County far enough to include Limon, which is the largest town in Lincoln County with a population of 1,880 (Suburban Stats, 2017).

\section{Previous Studies}

Previous studies of the UBSDGB alluvial aquifer include a groundwater-flow model of the Denver Basin aquifer system (Paschke, 2011) and previous aquifer-specific water-budget estimates (Martin and Wood Water Consultants, Inc., 2009). Paschke (2011) was part of a nationwide USGS project focused on updating groundwater availability assessments of principal aquifers. Paschke (2011) evaluated the hydrologic effects of development on Denver Basin groundwater resources and documented the Denver Basin groundwater-flow model, including results of model sensitivity. These results were used to identify areas of the system where additional data would improve the model calibration and predictions (Paschke, 2011). The Denver Basin model simulates groundwater flow in the Denver Basin bedrock aquifers and the overlying alluvial aquifers three dimensionally for the period from 1880 through 2003. Model predictions for the period 2004-2053 provide estimates of the future hydrologic system response to continued development (Paschke, 2011). Simulation results indicate that pumping from bedrock aquifers can lower hydraulic heads and deplete aquifer storage in bedrock units as well as overlying alluvial aquifers. The increase in downward gradients reduces discharge from bedrock units to the alluvial aquifers and streams and increases downward flow between bedrock layers (Paschke, 2011).

Martin and Wood Water Consultants, Inc. (2009) conducted a study to assess the consumptive and nonconsumptive water needs within the UBSDGB and compared those needs against the sustainable available water supply using a water-balance assessment approach. Consumptive 
water needs were defined as those that once used will not be returned to the source; in contrast, non-consumptive water needs were those that after use are returned to the source and can be reused. In the UBSDGB, consumptive water needs included phreatophyte use, groundwater leaving the UBSDGB (underflow), and stock watering; the non-consumptive water needs consisted of municipal and irrigation pumping (Martin and Wood Water Consultants, Inc., 2009). Martin and Wood Water Consultants, Inc. (2009) also quantified the volume of alluvial groundwater stored within the aquifer and estimated the economically recoverable quantity of this water. The water-budget components quantified included precipitation recharge, irrigation return flows, and municipal wastewater return flows as inflows to the UBSDGB alluvial aquifer. The outflow components were irrigation pumping, municipal pumping, stock watering, phreatophyte use, and groundwater leaving the UBSDGB (Martin and Wood Water Consultants, Inc., 2009). Martin and Wood Water Consultants, Inc. (2009) developed four water balances: average year, wet year, dry year, and permitted pumping. All water balances except the wet-year scenario indicated a net reduction of aquifer storage. Also, the major inflow component to the UBSDGB alluvial aquifer was recharge from precipitation, and the major outflows from the aquifer were to phreatophyte use and irrigation pumping. Martin and Wood Water Consultants, Inc. (2009) indicate that water levels within the UBSDGB, under 2009 climate (average rainfall year) and pumping conditions, are likely to decline unless there are multiple wet years.

The UBSDGB alluvial aquifer was determined to be over appropriated because an average precipitation year water balance predicted an approximately 2,100 acre-feet (ac-ft) reduction of aquifer storage, based on the 2009 aquifer use, which corresponded to an anticipated drop in the water table of less than 2 inches (Martin and Wood Water Consultants, Inc., 2009). As a result of the findings in Martin and Wood Water Consultants, Inc. (2009), the CGWC closed the UBSDGB to the drilling of new high-capacity (irrigation, municipal) wells in 2010. In 2011, the Upper Big Sandy Groundwater Management District drafted new regulations to restrict practices that would adversely affect the UBSDGB alluvial aquifer, replacing rules that had been adopted in May 1992 (Upper Big Sandy Groundwater Management District, 2018).

\section{Purpose and Scope}

The purpose of this report is to present an updated waterbudget analysis for the UBSDGB alluvial aquifer, including groundwater flow between the UBSDGB alluvial aquifer and the Denver Basin bedrock aquifers, and annual change in groundwater storage in 2016. This updated water budget was determined by combining water-budget information from an existing Denver Basin model (Paschke, 2011) for about threefourths of the study area with best estimates for the major water-budget components for the area outside the Denver Basin model area. Components of the UBSDGB alluvial aquifer water budget are shown in figures and tables.

\section{Methods}

A groundwater budget is an itemized list of the sources and quantities of water recharging an aquifer and the sources and quantities of water discharging from the aquifer (Robson, 1983 ) or more simply, an accounting budget of all water entering and leaving an aquifer. The change in aquifer storage is the difference between the sum of inflows to and outflows from an aquifer (Anderson and Woessner, 1992). A groundwaterflow model digitally represents an aquifer system and includes information on recharge, discharge, and aquifer properties for groundwater-flow simulation. Results from a groundwaterflow simulation include the distribution of hydraulic heads in an aquifer as well as a water budget, information on groundwater flow in aquifers, and the effects of development on groundwater resources. This makes a groundwater-flow model a useful tool for evaluating aquifer recharge, discharge, and water budgets (Anderson and Woessner, 1992) as well as for analyzing past and present conditions (Paschke, 2011).

This report presents estimates of water-budget components for the UBSDGB alluvial aquifer within the UBSDGB. To estimate the water-budget components for the UBSDGB alluvial aquifer, budget components for the modeled area and the unmodeled area of the UBSDGB alluvial aquifer were estimated separately, and then the results were combined for an overall water-budget estimate. A USGS data release of all the input and output files for the simulation and calibration described in Paschke and others (2011) was published by Banta and others (2017). A second USGS data release archiving the modeling input and output files for the simulation described in this report for this study was published by Kohn (2019).

\section{Water-Budget Components within Denver Basin Modeled Area}

The water-budget components were estimated for the modeled area using outputs from the Denver Basin model, which uses the modular finite-difference groundwater flow computer model MODFLOW-2000 (Harbaugh and others, 2000) with 1-mile (mi) grid cells (Paschke, 2011). A basin-specific water budget for the UBSDGB alluvial aquifer was extracted from the Denver Basin model results using the tool ZONEBUDGET (Harbaugh, 1990). ZONEBUDGET is a computer model that calculates a water budget for a specified subarea of a groundwater model. For the present study, the subarea is the alluvial aquifer within the UBSDGB. In the Denver Basin model, alluvial aquifers were represented as the top geologic layer (layer 1) of the 12-layer model, and the UBSDGB alluvial aquifer was included as part of the layer 1 alluvial aquifers.

\section{Denver Basin Model Updates}

Groundwater storage change within the UBSDGB alluvial aquifer was determined by updating water-budget components from the Denver Basin model (Paschke, 2011) for the UBSDGB 
modeled area. The inflow components considered were recharge from precipitation and irrigation return flows, inflow from streams, groundwater inflow from adjacent alluvial aquifers, groundwater inflow from underlying bedrock aquifers, and groundwater inflow from upgradient areas. In the Denver Basin model (Paschke, 2011), the water-budget component, recharge, included precipitation and return flows from agriculture irrigation and urban applications, such as lawn irrigation and general water use. The urban recharge rate was applied to urban areas within the model extent on the basis of land-use mapping (Paschke, 2011). Because no urban land-use areas were delineated by Paschke (2011) in the modeled area of the UBSDGB, the recharge inflow component for this study includes only precipitation and return flows from agriculture irrigation (irrigation return flows). Because the western extent of the UBSDGB begins at the headwaters of the Big Sandy Creek at a topographic divide, there is no groundwater inflow from upgradient areas external to the UBSDGB, and this groundwater inflow component from upgradient areas is zero for water-budget calculations of the modeled area. The outflow components considered were evapotranspiration, pumping wells, groundwater outflow to streams, groundwater outflow to adjacent alluvial aquifers, groundwater outflow to underlying bedrock aquifers, and downgradient groundwater flow out of the UBSDGB. The water-budget components for the unmodeled area were estimated based on area- or length-weighted flow rates from the modeled-area results and other published resources.

Because the modeled area includes the bedrock aquifers that underlie the UBSDGB alluvial aquifer, the calculated water budget includes recharge from or discharge to (interaction between) the alluvial and bedrock aquifers. This water-budget component was not included in previous water-budget estimates for the UBSDGB alluvial aquifer (Martin and Wood Water Consultants, Inc., 2009). The interaction between the UBSDGB alluvial aquifer and the underlying bedrock units could potentially be an important component of the water budget. This water-budget component for predevelopment conditions of the entire Denver Basin model represented a net outflow from the bedrock units to the alluvial aquifers (Paschke, 2011). Net inflow or outflow is the difference between the inflow and outflow of a budget component. Paschke (2011) indicates that over time (1880 through 2003) the entire Denver Basin had a decrease in simulated outflow from the bedrock units to the alluvial aquifers and, inversely, an increase in simulated inflow to the bedrock units from the alluvial aquifers.

The Denver Basin model was calibrated for 1880 to 2003 on the basis of hydraulic heads and streamflows by adjusting primarily aquifer hydraulic conductivity and recharge, along with many other model parameters (Paschke, 2011). For this study, the Denver Basin model was updated with additional information from 2004 through 2016 for the study area to generate 2016 estimates of the water budget in the UBSDGB alluvial aquifer. The Denver Basin model presented in Paschke (2011) incorporated well pumpage data for municipal, irrigation, commercial, industrial, domestic, livestock, and household uses through 2003. For the current study, the well data file was updated to include consumptive water use from pumping wells in the UBSDGB from 2004 through 2016. The temporal variability of land cover in the UBSDGB was verified by reviewing the 2003 through 2016 U. S. Department of Agriculture CropScape land cover dataset (U.S. Department of Agriculture, 2017). There was no evidence of large-scale land-use change (rangeland to cropland or urban) from 2003 through 2016 in the UBSDGB, so recharge from precipitation and irrigation return flows, and corresponding evapotranspiration estimates, were simulated from 2003 through 2016 using 2003 values.

\section{Alluvial Aquifer Inflows}

The water budget calculated with ZONEBUDGET utilizes output files from the Denver Basin model, so the UBSDGB alluvial aquifer water-budget components are the same as those identified by Paschke (2011). The inflow components of the modeled area of UBSDGB alluvial aquifer tabulated by ZONEBUDGET were (1) recharge from precipitation and irrigation return flows, (2) inflow from streams, (3) groundwater inflow from adjacent alluvial aquifers, (4) groundwater inflow from underlying bedrock aquifers, and (5) inflow from storage.

Recharge for the period 2000 through 2003 was used for Denver Basin model runs from 2004 through 2016 because 2000 to 2003 were identified by Paschke (2011) as drought years. To set up the ZONEBUDGET extraction of waterbudget information from the Denver Basin model, a zone representing the geographic footprint of the UBSDGB alluvial aquifer was designated in each of the 12 model layers following the alluvial aquifer designation in Paschke (2011). This new zone (Zone 13 in ZONEBUDGET) consists of 104 grid cells in layer 1 of the Denver Basin model (Paschke, 2011) or an area of $104 \mathrm{mi}^{2}$ (fig. 2). The calibrated recharge values from the Denver Basin model were used by ZONEBUDGET to estimate the recharge in the Zone 13 grid cells for the uppermost layer. A large alluvial aquifer (Nussbaum Alluvium, Zone 1 in ZONEBUDGET; fig. 3) is south and adjacent to the UBSDGB along the headwaters of Middle Rush Creek, Mustang Creek, Adobe Creek, Horse Creek, and Steels Fork (fig. 3). The flow between the Nussbaum Alluvium and the UBSDGB alluvial aquifer was estimated by ZONEBUDGET by calculating the flow between Zone 1 (adjacent alluvial aquifers) and Zone 13 (UBSDGB alluvial aquifer). Additionally, groundwater inflows from underlying bedrock aquifers into the UBSDGB alluvial aquifer were estimated by ZONEBUDGET by calculating the flow from Zones 2 through 12 (all confined aquifers or confining layers in the Denver Basin model) to Zone 13 (UBSDGB alluvial aquifer). Flows into and out of stream cells as defined in the Denver Basin model also were estimated by ZONEBUDGET. Based on the other inflow and outflow component calculations for the UBSDGB alluvial aquifer, ZONEBUDGET calculated an estimate of the inflow and outflow components from storage. 


\section{Alluvial Aquifer Outflows}

The outflow components of the modeled part of the UBSDGB alluvial aquifer calculated by ZONEBUDGET were (1) evapotranspiration, (2) pumping wells, (3) groundwater outflow to streams, (4) groundwater outflow to adjacent alluvial aquifers, (5) groundwater outflow to underlying bedrock aquifers, (6) groundwater outflow leaving the modeled area and entering the unmodeled area, and (7) outflow to storage. The calibrated evapotranspiration values from the Denver Basin model in Paschke (2011) were not changed for the 2004 through 2016 model simulations. Paschke (2011) estimated pumping from 1880 through 2003 using a geographical information system and database analysis from the 2004 version of the Colorado Division of Water Resources well-permit database. Pumpage from each of the aquifers was estimated as the product of the number of wells multiplied by the appropriate pumping rate for the well type. Pumping rates were assigned based on water use, dates of use, and aquifer designation. The water-use categories were limited to municipal, irrigation, commercial or industrial, domestic and livestock, and household only.

To compute the 2016 water budget, the well data file for the Denver Basin model (Paschke, 2011), which included 1,257 pumping wells screened in the alluvial and bedrock aquifers in the modeled area, was updated with well pumpage data from 2004 through 2016. In this report, pumping rates were estimated from 2004 through 2016 using the rates established in Paschke (2011) and are shown in table 1.

The Colorado Division of Water Resources well-permit database (Colorado Division of Water Resources, 2017c) was queried for newly constructed wells and abandoned wells from 2004 through 2016 for the three counties which overlie the UBSDGB. Well locations and aquifer designations were checked, and only wells located within the UBSDGB that were permitted and completed prior to December 31, 2016, were included in the analysis. Wells that were planned or provisional, monitoring wells, wells used for geothermal heating, remediation wells, and wells with insufficient location or completion data were excluded. The well data file for the Denver Basin model was updated with 124 pumping wells screened in the alluvial and bedrock aquifers in the modeled area after the addition of newly constructed wells and removal of wells identified as abandoned from 2004 through 2016, resulting in a total of 1,381 pumping wells in the modeled area.

Groundwater flows from the UBSDGB alluvial aquifer to streams, flow to adjacent alluvial aquifers, flow to underlying bedrock aquifers, and flow out of the modeled area were then calculated by ZONEBUDGET from the updated Denver Basin model. The groundwater outflow leaving the upgradient modeled area and entering the unmodeled area was also calculated by ZONEBUDGET as a head-dependent boundary. Based on the other inflow and outflow component calculations for the UBSDGB alluvial aquifer, ZONEBUDGET calculated an estimate of the inflow and outflow components to storage.

\section{Water-Budget Components within Unmodeled Area}

The water-budget components for the unmodeled area were estimated using a combination of available resources. The components of the water budget for the unmodeled area were based on results from the updated Denver Basin model and ZONEBUDGET estimations extrapolated to the unmodeled area.

\section{Alluvial Aquifer Inflows}

The inflow components of the UBSDGB alluvial aquifer estimated for the unmodeled area were (1) recharge from precipitation and irrigation return flows, (2) inflow from streams, (3) groundwater inflow from adjacent alluvial aquifers,

(4) groundwater inflow from the upgradient modeled area, and (5) inflow from storage. There was no groundwater flow to the UBSDGB alluvial aquifer from underlying bedrock aquifers for the unmodeled area because the UBSDGB alluvial aquifer in the unmodeled area is underlain by the Cretaceous Pierre Shale, which is generally considered the basal confining unit of the Denver Basin aquifer system.

To estimate recharge for the unmodeled area, an areaweighted average recharge was computed from the simulated 2003 recharge (Paschke, 2011, fig. B30). This area-weighted average (38.9 ac-ft/year [yr] per $\mathrm{mi}^{2}$ ) for the modeled area was multiplied by the area of the unmodeled area $\left(111 \mathrm{mi}^{2}\right)$,

Table 1. Assigned pumpage rates for wells in the Upper Big Sandy Designated Groundwater Basin, Colorado.

[Modified from table B1 in Paschke, 2011]

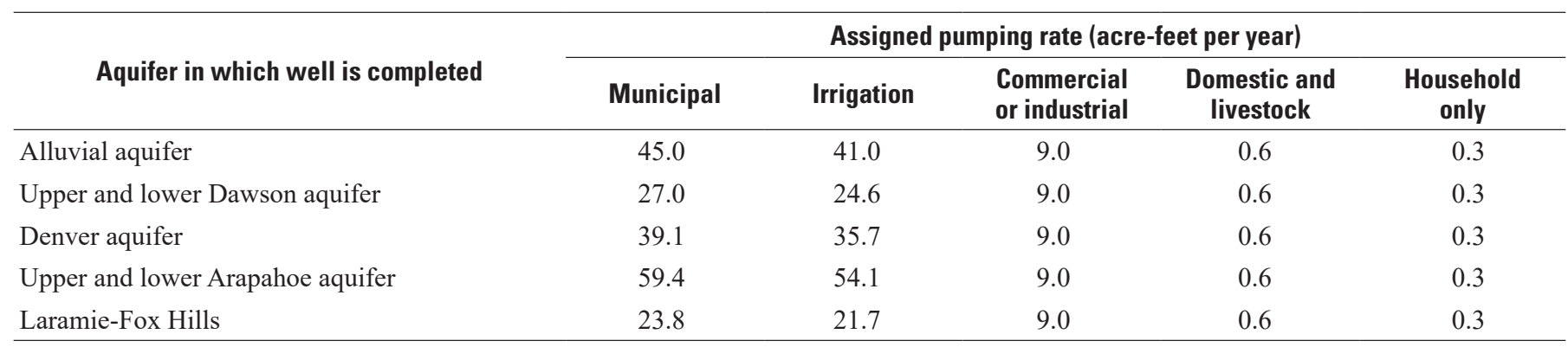


resulting in an estimate of the 2016 recharge for the unmodeled area in acre-feet.

Groundwater inflow to the UBSDGB alluvial aquifer from streams was estimated for the unmodeled area on the basis of groundwater inflow from streams computed by the Denver Basin model (Paschke, 2011, fig. B39). Positive groundwater flow represents recharge (inflow) from streams, and negative groundwater flow represents discharge (outflow) to streams. The area-weighted average of groundwater inflow from streams was computed for the alluvial streambed of Big Sandy Creek for the modeled area. Then, this area-weighted average of groundwater flow $\left(0.55 \mathrm{ac}-\mathrm{ft}\right.$ per $\left.\mathrm{mi}^{2}\right)$ from streams was multiplied by the area $\left(21.1 \mathrm{mi}^{2}\right)$ of the alluvial streambed of Big Sandy Creek in the unmodeled area, resulting in an estimate of the 2016 groundwater inflow from streams, in acre-feet. These calculations assume that groundwater-surface-water interactions are uniform along Big Sandy Creek in the study area.

Groundwater flow into the unmodeled area from adjacent alluvial aquifers and from the upgradient modeled area was estimated in two parts. First, the inflow from adjacent alluvial aquifers was calculated for the modeled area as the flow from Zone 1 (Nussbaum Alluvium) to Zone 13 along the southern aquifer border as previously described in the "Water-Budget Components within Denver Basin Modeled Area" section. The calculated flow into the UBSDGB from the adjacent alluvial aquifer in the modeled area was then multiplied by the ratio of the lengths of the adjacent alluvial aquifer borders in the unmodeled and modeled areas to estimate the groundwater inflow from adjacent alluvial aquifers to the unmodeled area. Second, the groundwater flow out of the modeled area and into the unmodeled area was equal to the groundwater flow leaving the UBSDGB along the boundary between the areas (fig. 2). This groundwater flow was computed by MODFLOW headdependent boundaries and tabulated by ZONEBUDGET.

\section{Alluvial Aquifer Outflows}

The outflow components of the UBSDGB alluvial aquifer for the unmodeled area were (1) evapotranspiration, (2) pumping wells, (3) groundwater outflow to streams, (4) groundwater outflow to adjacent alluvial aquifers, and (5) groundwater outflow to downgradient areas from the UBSDGB. To compute the evapotranspiration for the unmodeled area, area-weighted averages of the simulated 2003 recharge minus evapotranspiration (net recharge) (Paschke, 2011, fig. B34) were computed separately for the area encompassing the Big Sandy Creek alluvial streambed and adjacent flood plain, the area within the UBSDGB to the north of Big Sandy Creek, and the area within the UBSDGB south of Big Sandy Creek (fig. 2). The area-weighted averages for these three regions of the modeled area were multiplied by their respective areas in the unmodeled area, which resulted in an estimate of the 2016 net recharge for unmodeled area. For the unmodeled area, 2016 net recharge was subtracted from 2016 recharge, which resulted in 2016 evapotranspiration.

Paschke (2011) estimated groundwater withdrawals from pumping wells for 1880 through 2003 using the 2004 version of the Colorado Division of Water Resources wellpermit database. Pumpage estimates were updated using the 2017 version of the Colorado Division of Water Resources well-permit database (Colorado Division of Water Resources, 2017c) following methods used by Paschke (2011). Wells that were planned or provisional, monitoring wells, wells used for geothermal heating, remediation wells, and wells with insufficient location or completion data were excluded. A total of 137 pumping wells all screened in the UBSDGB alluvial aquifer in the unmodeled area were compiled for 2016 only. Total pumpage volume from wells screened in the UBSDGB alluvial aquifer in the unmodeled area was estimated for 2016 using the rates established in Paschke (2011; table 1). In addition, data on the measured 2016 total pumpage volume from 11 municipal wells were received from the Town of Limon (Dave Stone, Town of Limon Town Manager, written commun., July, 12, 2017) and were included in the analysis. Table 2 displays the net increase in pumping wells, by use and aquifer, which were added in the UBSDGB alluvial aquifer (for modeled and unmodeled areas) from 2004 through 2016. During this time, there was an increase of 154 pumping wells in the UBSDGB-124 pumping wells in the modeled area and 30 in the unmodeled area. The increase in pumping wells constructed in the UBSDGB (for both modeled and unmodeled areas) from 2004 through 2016 (using 2003 as a baseline) is shown in figure 5. Figure 5 also displays the total number of pumping wells in the UBSDGB (for modeled and unmodeled areas) from 2004 through 2016. In 2016, there were 1,518 pumping wells in the UBSDGB $(1,381$ pumping wells in the modeled area and 137 in the unmodeled area; fig. 6), which is an increase from 2003 when 1,364 pumping wells $(1,257$ pumping wells in the modeled area and 107 in the unmodeled area ) existed.

Groundwater outflow to streams was estimated for the unmodeled area in the same manner as was the groundwater inflow from streams for the unmodeled area. The areaweighted average of groundwater outflow to streams was computed for the alluvial streambed of Big Sandy Creek for the modeled area. Then, this area-weighted average of groundwater flow to streams $\left(-15.6 \mathrm{ac}-\mathrm{ft}\right.$ per $\left.\mathrm{mi}^{2}\right)$ was multiplied by the area $\left(21.1 \mathrm{mi}^{2}\right)$ of the alluvial streambed of Big Sandy Creek in the unmodeled area, resulting in an estimate of groundwater outflow to streams in 2016 for the unmodeled area.

Groundwater flow out of the unmodeled area to adjacent alluvial aquifers was estimated in the same manner as the groundwater flow into the unmodeled area from adjacent alluvial aquifers. Outflow to adjacent alluvial aquifers was calculated for the modeled area as the flow to Zone 1 (Nussbaum Alluvium) from Zone 13 along the southern aquifer border as previously described in the section "WaterBudget Components within Denver Basin Modeled Area." The calculated flow from the UBSDGB to the adjacent alluvial aquifer in the modeled area was then multiplied by the ratio of the lengths of the adjacent alluvial aquifer borders in the unmodeled and modeled areas to estimate the alluvial groundwater inflow to the adjacent alluvial aquifers. 
Table 2. Net Increase in pumping wells from 2004 through 2016 in the Upper Big Sandy Designated Groundwater Basin in modeled and unmodeled areas in Colorado.

[Positive values equate to a net increase in wells and negative values equate to a net decrease in wells]

\begin{tabular}{|c|c|c|c|c|c|c|}
\hline $\begin{array}{l}\text { Well } \\
\text { use }\end{array}$ & $\begin{array}{l}\text { Alluvial } \\
\text { aquifer }\end{array}$ & $\begin{array}{c}\text { Lower Dawson } \\
\text { aquifer }\end{array}$ & $\begin{array}{l}\text { Denver } \\
\text { aquifer }\end{array}$ & $\begin{array}{c}\text { Upper } \\
\text { Arapahoe } \\
\text { aquifer }\end{array}$ & $\begin{array}{l}\text { Lower } \\
\text { Arapahoe } \\
\text { aquifer }\end{array}$ & $\begin{array}{c}\text { Laramie-Fox Hills } \\
\text { aquifer }\end{array}$ \\
\hline Municipal & 1 & 0 & 0 & 0 & 0 & 0 \\
\hline Irrigation & 9 & 0 & 0 & 0 & 0 & 0 \\
\hline Commercial or industrial & 2 & 0 & 0 & 3 & 0 & 0 \\
\hline Domestic and livestock & 34 & 1 & 31 & 49 & -5 & 28 \\
\hline Household only & 0 & 0 & 1 & 0 & 0 & 0 \\
\hline Total (154) & 46 & 1 & 32 & 52 & -5 & 28 \\
\hline
\end{tabular}

Pumping wells through time in the Upper Big Sandy Designated Groundwater Basin

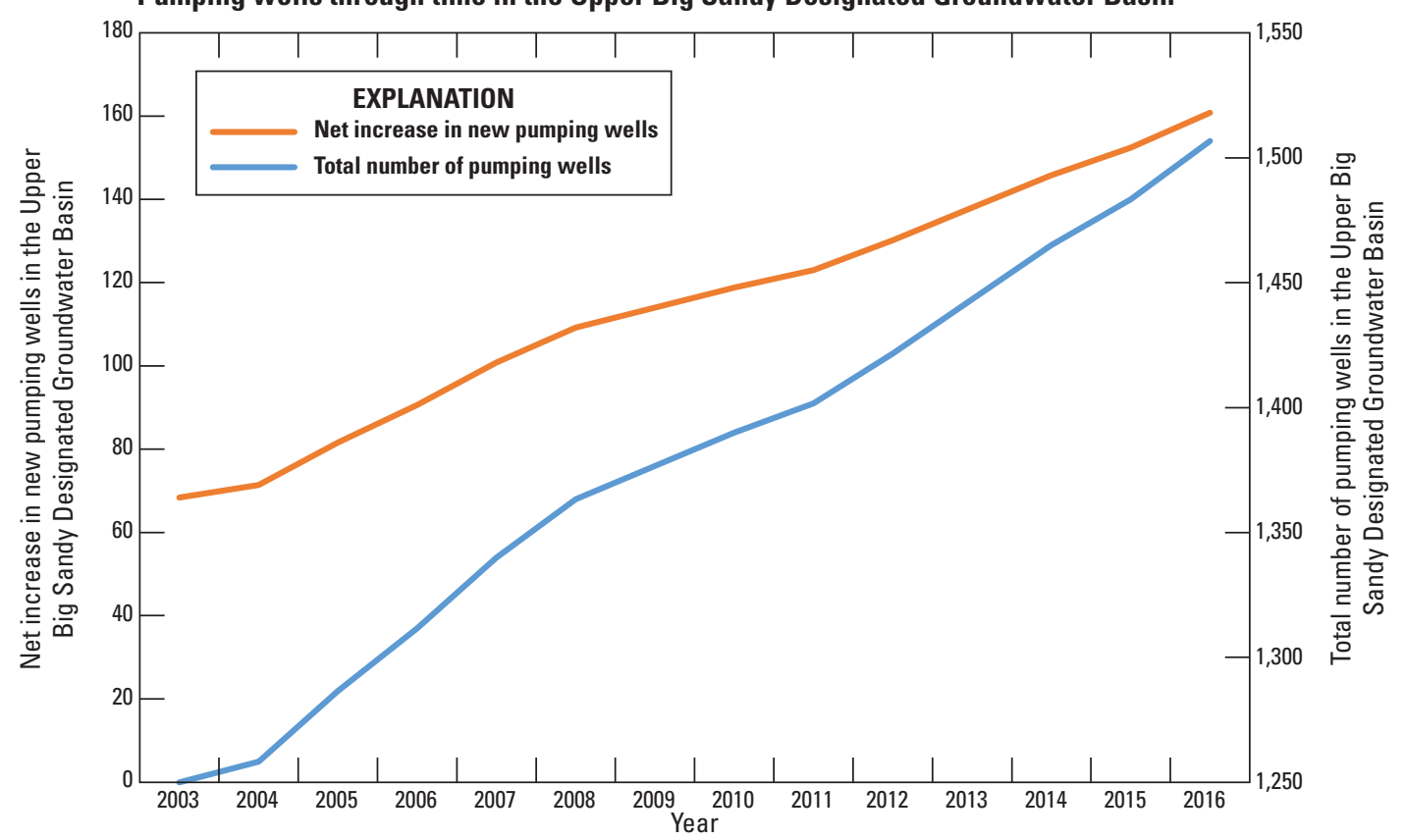

Figure 5. Net increase in new pumping wells and the total number of pumping wells from 2004 through 2016 in the Upper Big Sandy Designated Groundwater Basin in modeled and unmodeled areas in Colorado.

Groundwater outflow leaving the downgradient end of the UBSDGB unmodeled area was estimated to be 2,300 ac- $\mathrm{ft}$ per year (Martin and Wood Water Consultants, Inc., 2009). Martin and Wood Water Consultants, Inc. (2009) computed this value using average hydraulic conductivity, average hydraulic gradient, and estimated cross-sectional area of saturated material for the eastern edge of the basin boundary, and this value was used for the 2016 estimate of groundwater outflow leaving the UBSDGB at the downgradient end of the basin.

\section{Water-Budget Analysis}

The groundwater budgets presented here use the MODFLOW convention that positive values are inflows to, and negative values are outflows from, the groundwater system (Harbaugh and others, 2000). The inflows and outflows presented below are for the 2016 calendar year. Changes over time in the water budget of the UBSDGB alluvial aquifer are discussed in more detail in the "Change in Water-Budget Components Over Time" section. Results for both the modeled 


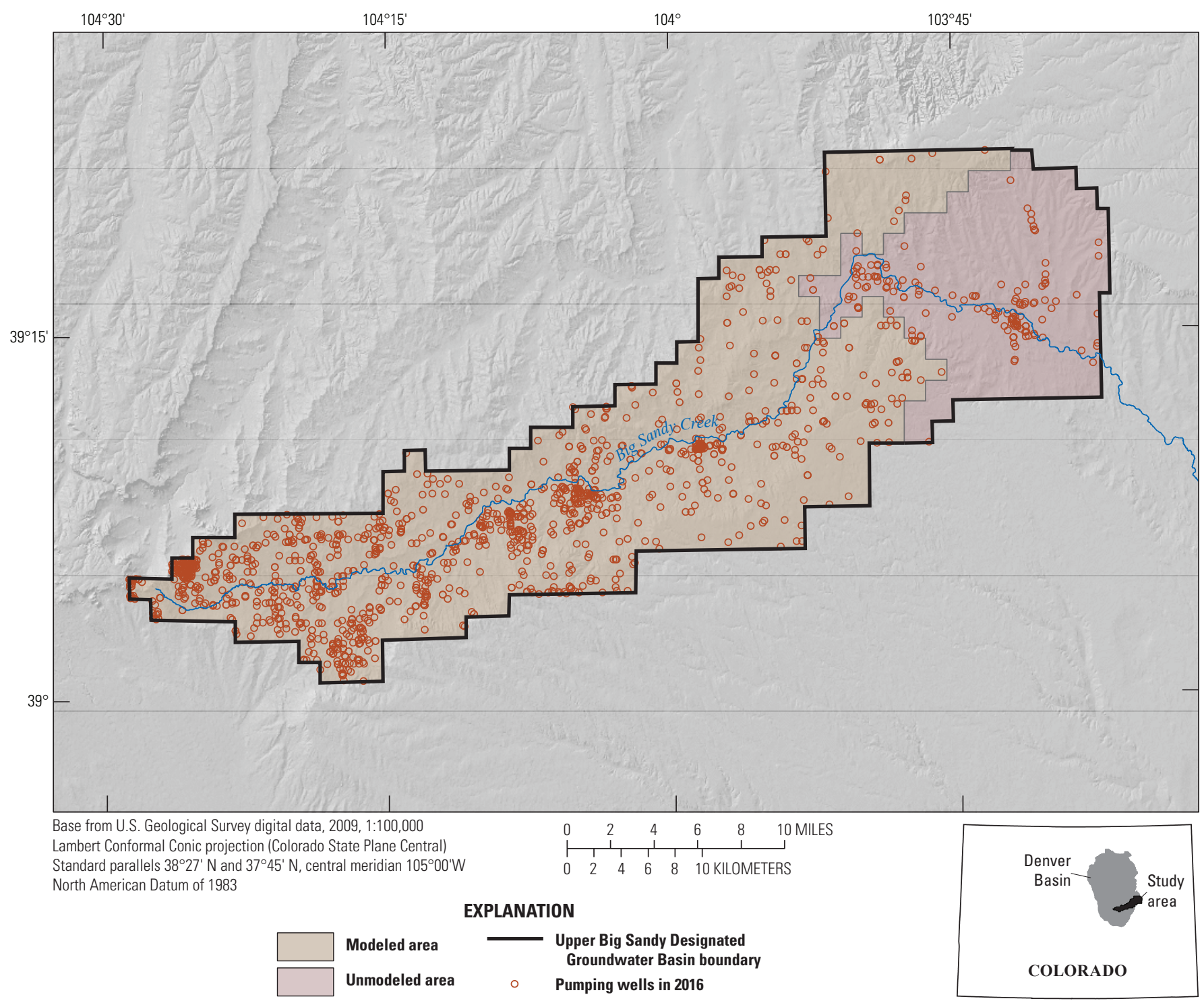

Figure 6. Location of the 1,512 pumping wells operating in the Upper Big Sandy Designated Groundwater Basin in modeled and unmodeled areas in Colorado, 2016.

and unmodeled areas are presented below for each component of the water budget, and for water-budget components with both inflows and outflows, the difference between inflow and outflow, or net flow, is discussed.

\section{Alluvial Aquifer Inflows}

Inflows to the UBSDGB alluvial aquifer in the modeled and unmodeled areas were (1) recharge from precipitation and irrigation return flows, (2) inflow from streams, (3) groundwater inflow from adjacent alluvial aquifers, and (4) inflow from storage. Groundwater inflow from underlying bedrock aquifers to the UBSDGB alluvial aquifer is included only for the modeled area because this area is underlain by the Denver Basin aquifer system. The UBSDGB in the unmodeled area directly overlies the Pierre Shale confining unit. Groundwater inflow from upgradient areas along the western border of each area is not included for the modeled area because the western extent of the UBSDGB modeled area begins at the headwaters of the Big Sandy Creek and there is no groundwater inflow from upgradient areas external to the UBSDGB. The 2016 UBSDGB alluvial aquifer inflows and outflows for the modeled area, inflows and outflows for the unmodeled area, and the net flows for the modeled and unmodeled areas combined are displayed in figures 7,8 , and 9 , respectively.

\section{Recharge}

Recharge from precipitation and irrigation return flows to the UBSDGB alluvial aquifer in the modeled area as computed by ZONEBUDGET for 2016 was $6,822 \mathrm{ac}-\mathrm{ft}$ 
1 percent

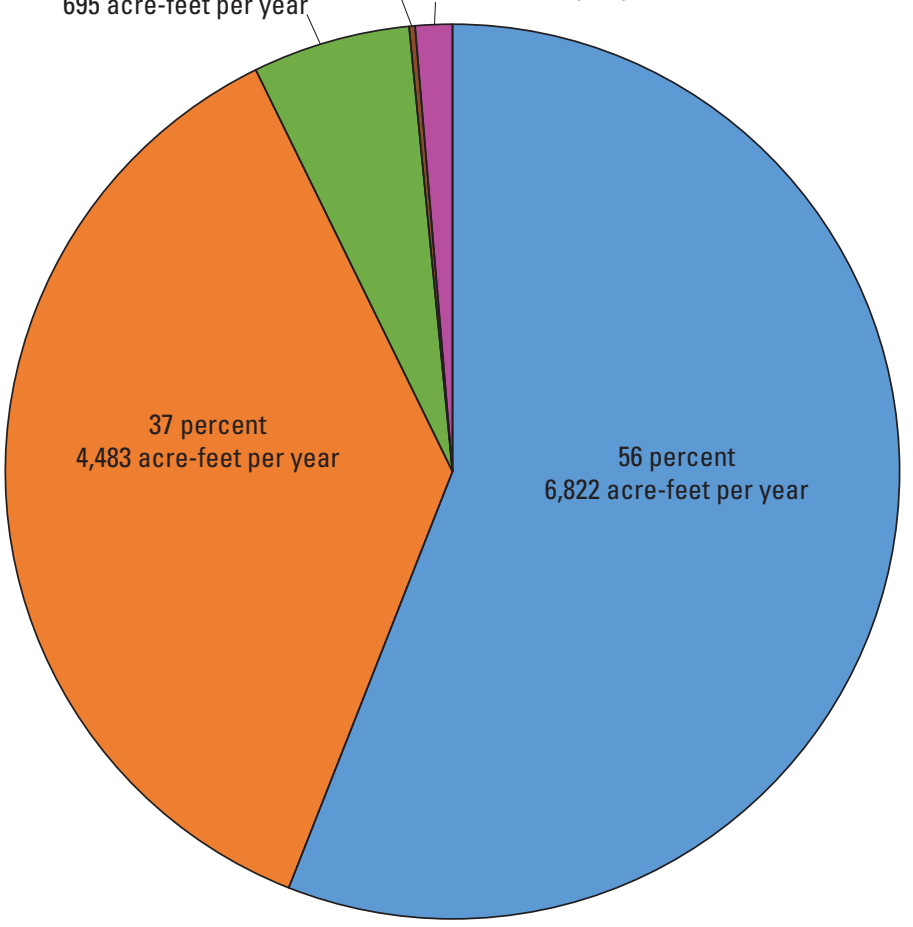

\section{EXPLANATION}

Recharge from precipitation and irrigation return flows

Inflow from adjacent alluvial aquifers

Inflow from underlying bedrock aquifers

Inflow from storage

Inflow from streams

B

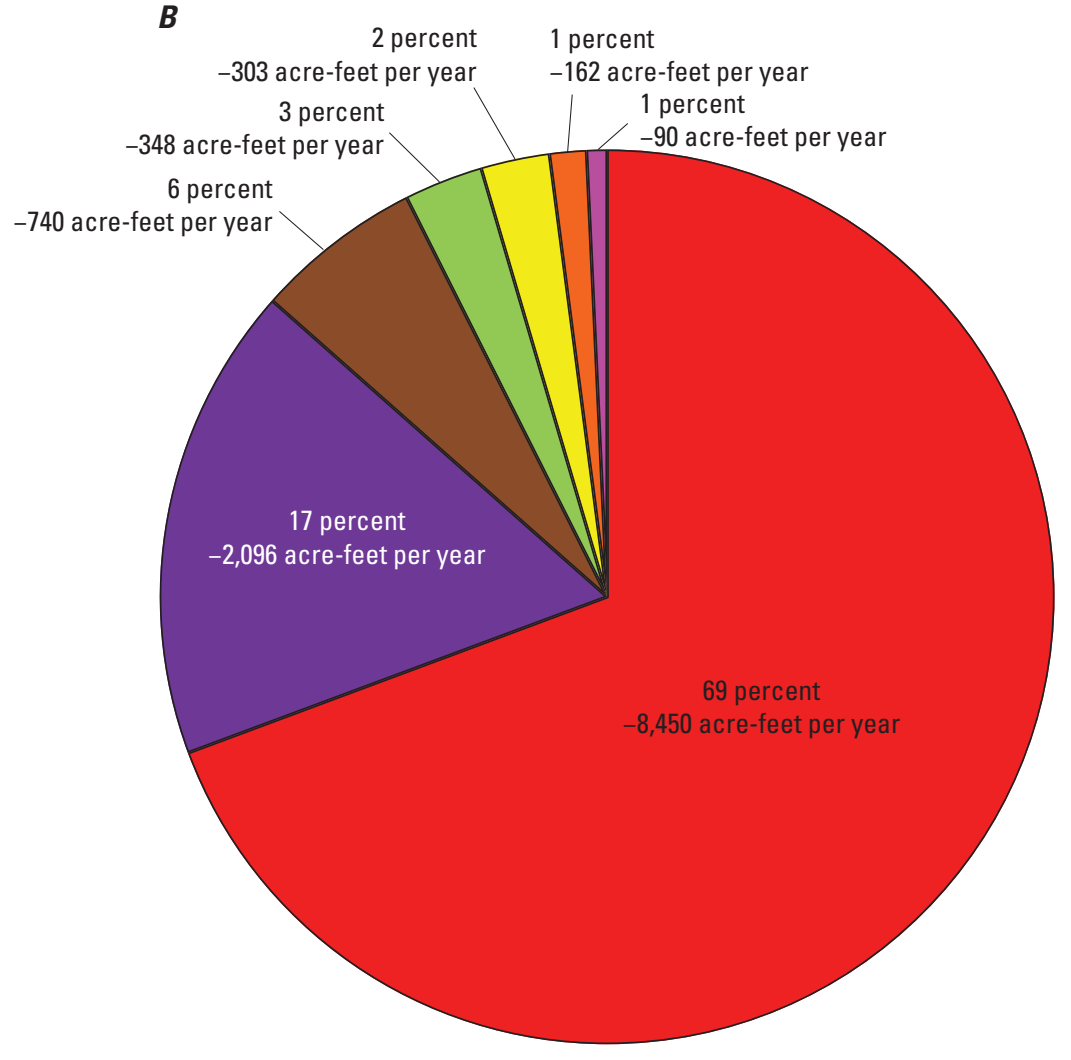

EXPLANATION

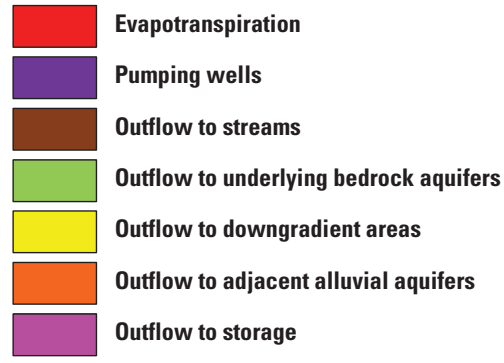

Figure 7. The 2016 Upper Big Sandy Designated Groundwater Basin alluvial aquifer $A$, inflows and $B$, outflows for the modeled area, Colorado. [Percentages were rounded to the nearest percent which is why the sum is not 100 percent] 


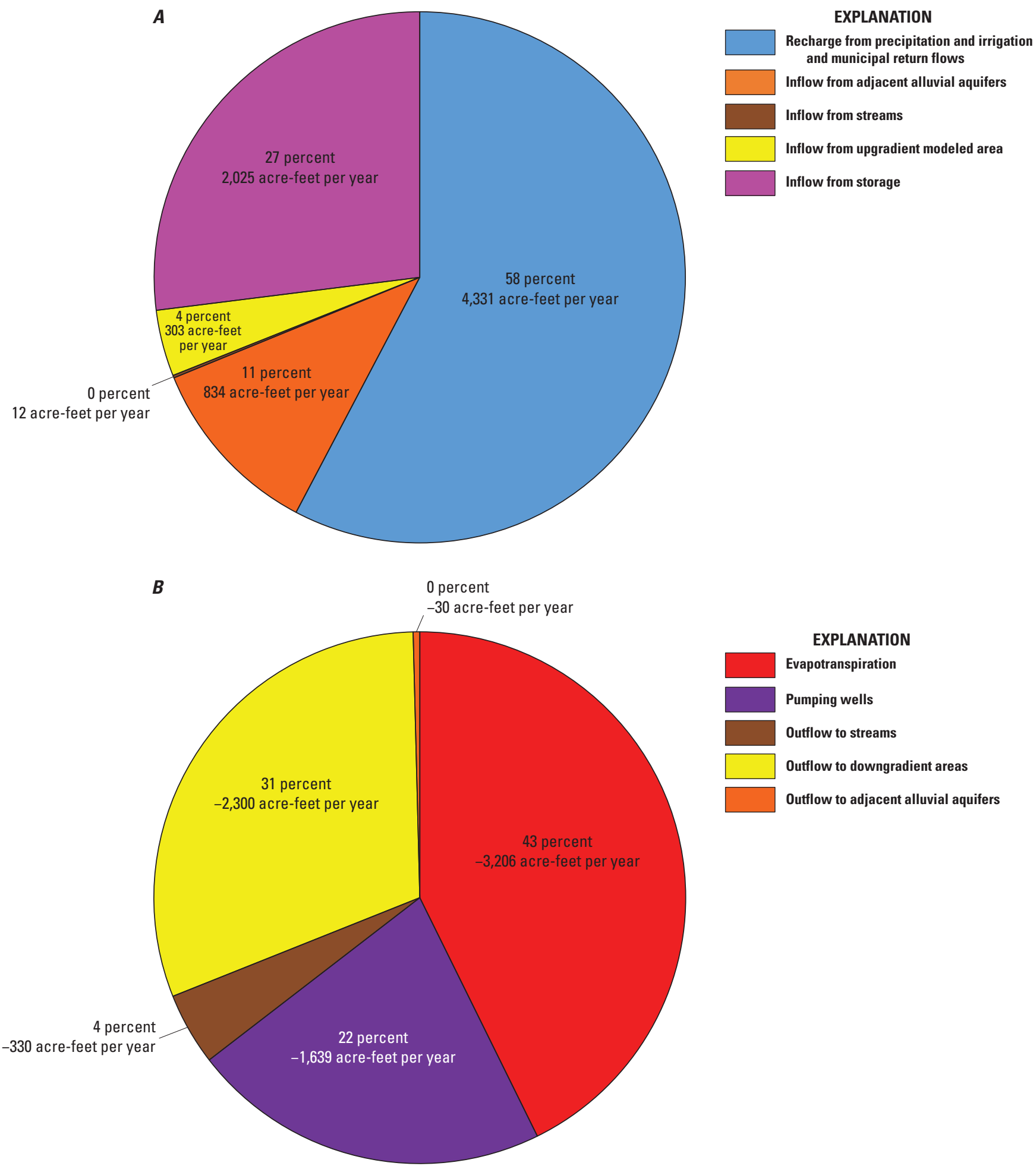

Figure 8. The 2016 Upper Big Sandy Designated Groundwater Basin alluvial aquifer $A$, inflows and $B$, outflows for the unmodeled area, Colorado. 


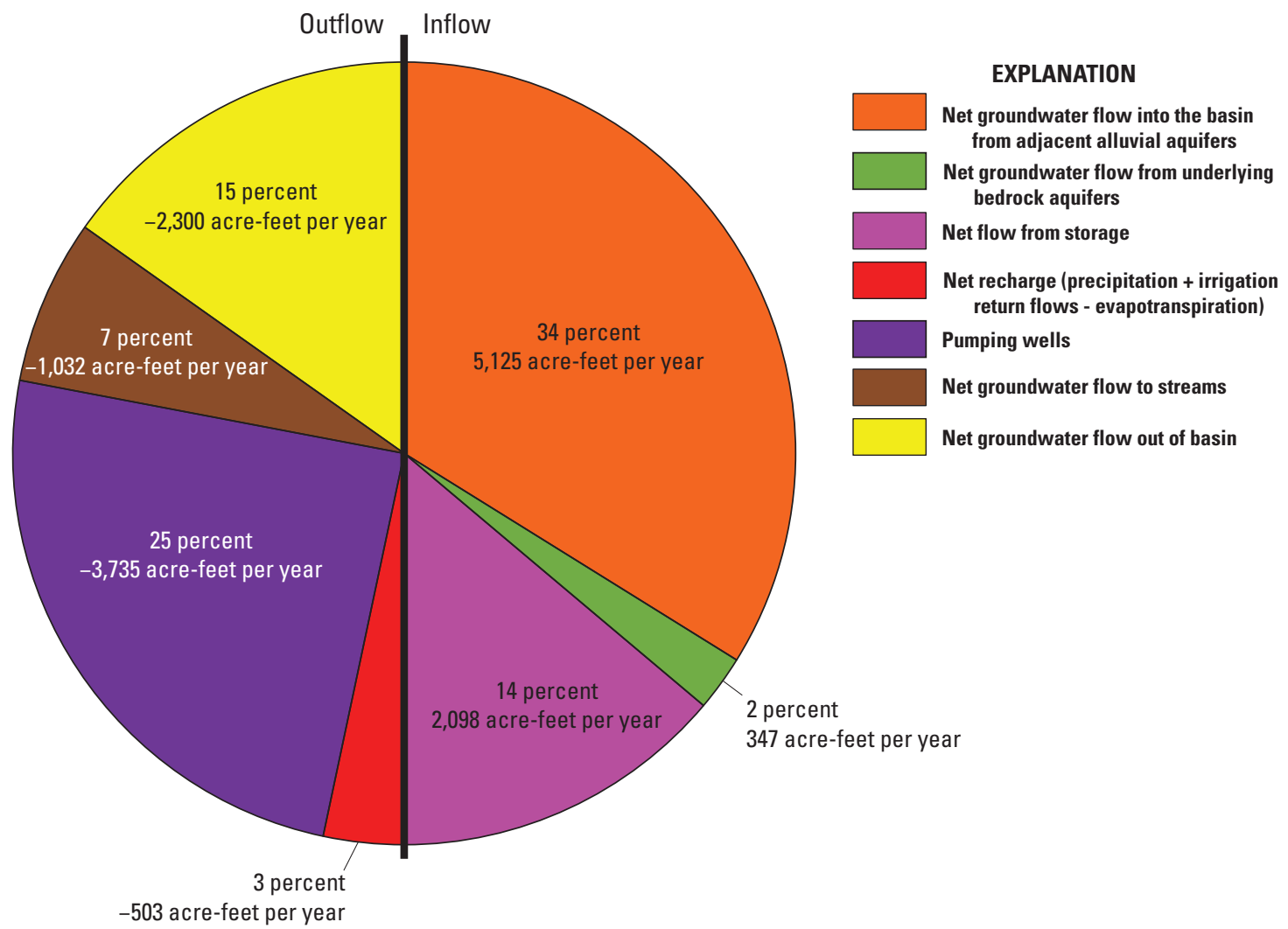

Figure 9. The 2016 Upper Big Sandy Designated Groundwater Basin alluvial aquifer net inflows and outflows for the modeled and unmodeled areas combined, Colorado.

Table 3. Water budget for the Upper Big Sandy Designated Groundwater Basin, modeled and unmodeled areas, in Colorado, 2016.

[Positive values are inflows to, and negative values are outflows from, the groundwater system]

\begin{tabular}{|c|c|c|c|}
\hline \multicolumn{4}{|c|}{ Inflows (acre-feet) } \\
\hline Water-budget component & Modeled area & Unmodeled area & Total area \\
\hline Recharge from precipitation and irrigation return flows & 6,822 & 4,331 & 11,153 \\
\hline Inflow from adjacent alluvial aquifers & 4,483 & 834 & 5,317 \\
\hline Inflow from underlying bedrock aquifers & 695 & 0 & 695 \\
\hline Inflow from streams & 26 & 12 & 38 \\
\hline Inflow from upgradient modeled area & 0 & 303 & 303 \\
\hline Inflow from storage & 163 & 2,025 & 2,188 \\
\hline Total & 12,189 & 7,505 & 19,694 \\
\hline \multicolumn{4}{|c|}{ Outflows (acre-feet) } \\
\hline Water-budget component & Modeled area & Unmodeled area & Total area \\
\hline Evapotranspiration & $-8,450$ & $-3,206$ & $-11,656$ \\
\hline Pumping wells & $-2,096$ & $-1,639$ & $-3,735$ \\
\hline Outflow to streams & -740 & -330 & $-1,070$ \\
\hline Outflow to underlying bedrock aquifers & -348 & 0 & -348 \\
\hline Outflow to downgradient areas & -303 & $-2,300$ & $-2,603$ \\
\hline Outflow to adjacent alluvial aquifers & -162 & -30 & -192 \\
\hline Outflow to storage & -90 & 0 & -90 \\
\hline Total & $-12,189$ & $-7,505$ & $-19,694$ \\
\hline
\end{tabular}


( $0.39 \mathrm{in} / \mathrm{yr}$ over the 211,560 acres of modeled area) (table 3 ). Recharge from precipitation and irrigation return flows to the UBSDGB alluvial aquifer in the unmodeled area, which was calculated from the results in the modeled area for 2016, was $4,331 \mathrm{ac}-\mathrm{ft}(0.73 \mathrm{in} / \mathrm{yr})$ (table 3). Combining the modeled and unmodeled recharge gives a total recharge of $11,153 \mathrm{ac}-\mathrm{ft}$ (0.48 in/yr) for the UBSDGB alluvial aquifer (table 3). Net recharge (precipitation and irrigation return flows minus evaporation) into the UBSDGB alluvial aquifer was negative with evaporation exceeding recharge such that groundwater is being removed from the UBSDGB alluvial aquifer. This component of the water budget is therefore discussed further in the "Evapotranspiration" section.

\section{Inflow from Streams}

Inflow from streams to the UBSDGB alluvial aquifer in the modeled area as computed by ZONEBUDGET for 2016 was $26 \mathrm{ac}-\mathrm{ft}(0.001 \mathrm{in} / \mathrm{yr})$ (table 3). Inflow from streams in the unmodeled area was 12 ac-ft (0.002 in/yr) (table 3), which was computed from the results for the modeled area for 2016. Combining the modeled and unmodeled inflow from streams results in a total inflow from streams of 38 ac-ft (0.002 in/yr) for the UBSDGB alluvial aquifer (table 3). The net flow between the UBSDGB alluvial aquifer and the stream network was negative (groundwater is discharging from the UBSDGB alluvial aquifer to the stream network); therefore, this component of the water budget is discussed further in the "Outflow to Streams" section.

\section{Inflow from Adjacent Alluvial Aquifers}

Inflow from adjacent alluvial aquifers in the modeled area was computed by ZONEBUDGET for 2016, resulting in a volume of 4,483 ac-ft (0.26 in/yr) (table 3). Inflow from adjacent alluvial aquifers in the unmodeled area was $834 \mathrm{ac}-\mathrm{ft}$ (0.14 in/yr) (table 3), which was computed from the results for the modeled area for 2016. Combining the modeled and unmodeled inflows from adjacent aquifers results in a total inflow from adjacent alluvial aquifers of 5,317 ac- $\mathrm{ft}(0.23 \mathrm{in} / \mathrm{yr})$ for the UBSDGB alluvial aquifer (table 3 ).

The net groundwater flow into the basin from adjacent alluvial aquifers was positive with flow entering the UBSDGB alluvial aquifer. Combining the total inflow from adjacent alluvial aquifers of 5,317 ac- $\mathrm{ft}$ and the total outflow to adjacent alluvial aquifers of $-192 \mathrm{ac}-\mathrm{ft}$ for the UBSDGB alluvial aquifer (table 3) results in a net flow from adjacent alluvial aquifers to UBSDGB alluvial aquifer of 5,125 ac-ft (0.22 in/yr) (fig. 9).

\section{Inflow from Underlying Bedrock Aquifers}

Inflow from the bedrock aquifers to the UBSDGB alluvial aquifer in the modeled area as computed by ZONEBUDGET for 2016 was $695 \mathrm{ac}-\mathrm{ft}(0.04 \mathrm{in} / \mathrm{yr}$ ) (table 3). The Laramie-Fox Hills aquifer provided the primary bedrock inflow to the UBSDGB alluvial aquifer (table 4). Although
Table 4. Net flow between the Upper Big Sandy Designated Groundwater Basin alluvial aquifer and adjacent bedrock aquifer units in Colorado.

[When net flow is positive, flow is entering the Upper Big Sandy Designated Groundwater Basin alluvial aquifer, and when net flow is negative, flow is leaving the Upper Big Sandy Designated Groundwater Basin alluvial aquifer]

\begin{tabular}{lc}
\hline \multicolumn{1}{c}{ Aquifer unit } & $\begin{array}{c}\mathbf{2 0 1 6} \text { net flow between aquifer } \\
\text { unit and the Upper Big Sandy } \\
\text { Designated Groundwater Basin } \\
\text { alluvial aquifer (acre-feet) }\end{array}$ \\
\hline Upper Dawson aquifer & $0.00^{1}$ \\
Dawson confining unit & $0.00^{1}$ \\
Lower Dawson aquifer & 16.5 \\
Denver upper confining unit & 0.00 \\
Denver aquifer & -56.0 \\
Denver lower confining unit & -142 \\
Upper Arapahoe aquifer & -80.4 \\
Arapahoe confining unit & 0.02 \\
Lower Arapahoe aquifer & -42.6 \\
Laramie confining unit & -26.6 \\
Laramie-Fox Hills aquifer & 678 \\
$\quad$ Total bedrock & $\mathbf{3 4 7}$ \\
\hline
\end{tabular}

${ }^{1}$ The upper Dawson aquifer and the Dawson confining unit are not immediately adjacent to the Upper Big Sandy Designated Groundwater Basin alluvial aquifer, so direct interaction is not possible.

the net flow from the bedrock aquifers was positive (into the UBSDGB alluvial aquifer), there was substantial outflow computed from the UBSDGB alluvial aquifer to the Denver lower confining unit, the upper Arapahoe aquifer, and Denver aquifer (table 4).

The net flow between the bedrock aquifers and the UBSDGB alluvial aquifer was positive with flow entering the UBSDGB alluvial aquifer from the bedrock aquifers. The net flow (inflow minus outflow) from the bedrock aquifers to the UBSDGB alluvial aquifer in the modeled area as computed by ZONEBUDGET for 2016 was $347 \mathrm{ac}-\mathrm{ft}$ (0.01 in/yr) (table 4, fig. 9). See the "Change in Water-Budget Components Over Time" section for a discussion of how the net flow from the bedrock units has changed over time. A map of the spatial distribution of the flow between the bedrock aquifers and the UBSDGB alluvial aquifer is displayed in figure 10. In the UBSDGB alluvial aquifer, the largest inflows from the bedrock aquifers occurred near the eastern and western ends of the modeled area, from the lower Dawson and Laramie-Fox Hills aquifers, respectively, whereas the central part of the UBSDGB alluvial aquifer modeled area experienced outflow to the bedrock aquifers and confining units (fig. 10).

\section{Inflow from Upgradient Modeled Area}

The flow between the UBSDGB alluvial aquifer in the modeled and unmodeled areas was positive with 


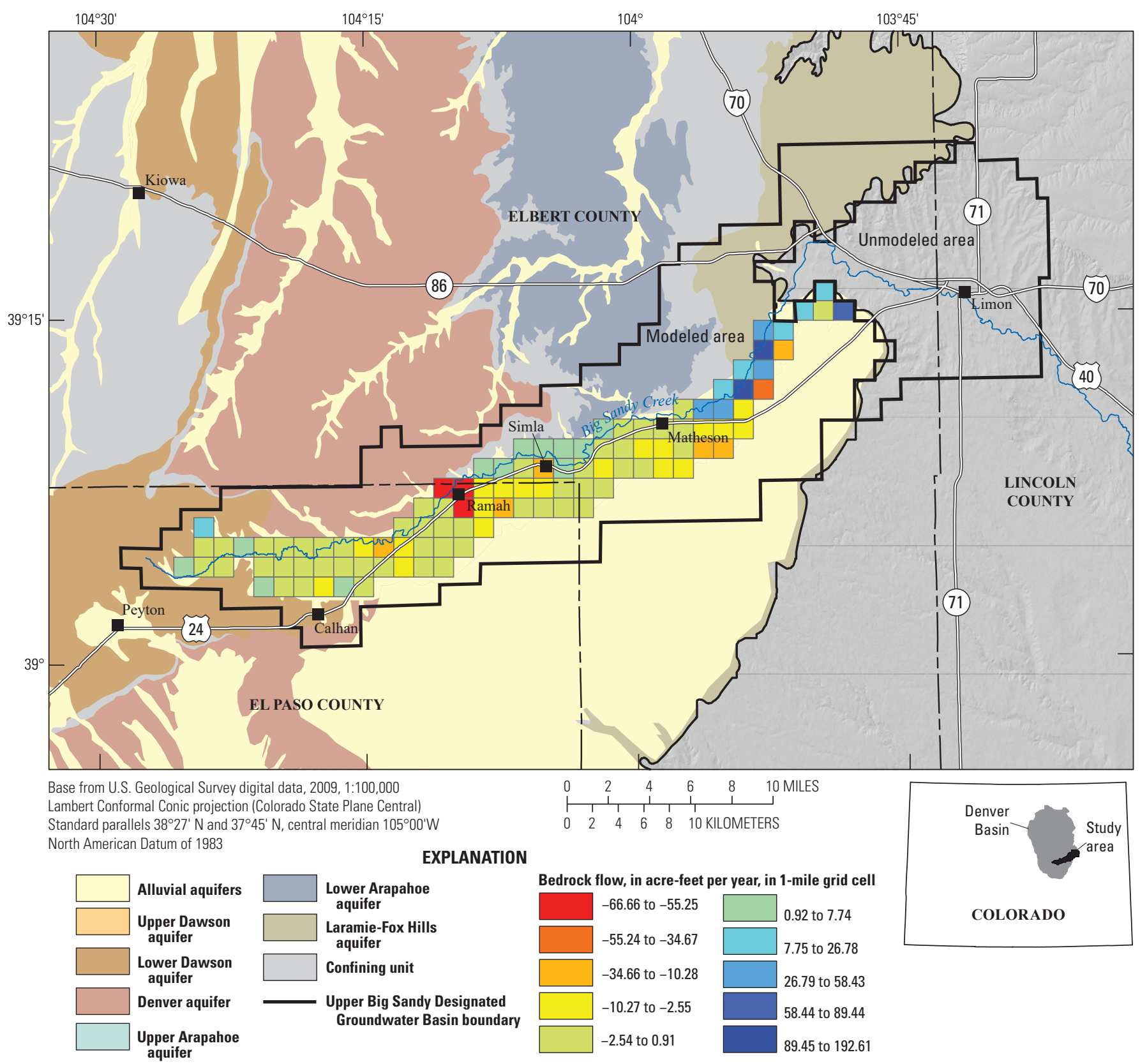

Figure 10. The spatial distribution of the flow between the bedrock aquifers and the Upper Big Sandy Designated Groundwater Basin alluvial aquifer in Colorado, 2016.

flow entering the downgradient unmodeled area from the upgradient modeled area. The groundwater inflow entering the unmodeled area from the modeled area as calculated by ZONEBUDGET for 2016 was 303 ac-ft (table 3). The net flow out of the UBSDGB alluvial aquifer for the basin was negative (groundwater is leaving the basin at the downgradient end of the UBSDGB alluvial aquifer); therefore, this component of the water budget is discussed further in the section "Outflow to Downgradient Areas from the Upper Big Sandy Designated Groundwater Basin."

\section{Inflow from Storage}

The net flow from groundwater storage in the UBSDGB alluvial aquifer was positive with flow entering the UBSDGB alluvial aquifer from storage. The inflow from groundwater storage in the UBSDGB alluvial aquifer as computed from ZONEBUDGET for 2016 was $163 \mathrm{ac}-\mathrm{ft}(0.01 \mathrm{in} / \mathrm{yr})$ with an outflow to storage of $-90 \mathrm{ac}-\mathrm{ft}(-0.01 \mathrm{in} / \mathrm{yr})$ for the modeled area (table 3 ), resulting in a net flow from storage for the modeled area of $73 \mathrm{ac}-\mathrm{ft}(0.004 \mathrm{in} / \mathrm{yr})$. 
Combining the inflow water-budget components for the unmodeled area excluding storage for 2016 results in a total inflow volume of 5,480 ac-ft, which is $2,025 \mathrm{ac}-\mathrm{ft}$ less than the total volume of outflows leaving the USDGB alluvial aquifer for the unmodeled area for 2016 of 7,505 ac-ft (table 3). Because of the deficit, $2,025 \mathrm{ac}-\mathrm{ft}(0.34 \mathrm{in} / \mathrm{yr})$ was removed from aquifer storage as an inflow to the UBSDGB alluvial aquifer to balance the UBSDGB alluvial aquifer water budget in the unmodeled area (table 3). Combining the net flow from storage for the modeled area of $73 \mathrm{ac}-\mathrm{ft}$ and the inflow from storage for the unmodeled area of 2,025 ac-ft results in a net positive flow from storage entering the UBSDGB alluvial aquifer for the basin of 2,098 ac-ft (0.09 in/yr) (fig. 9). This component is discussed further in the "Groundwater Storage" section.

\section{Alluvial Aquifer Outflows}

Outflows from the modeled and unmodeled areas of the UBSDGB alluvial aquifer were (1) evapotranspiration, (2) pumping wells, (3) groundwater outflow to streams,

(4) groundwater outflow to adjacent alluvial aquifers, and

(5) groundwater outflow leaving the UBSDGB. Groundwater outflow to underlying bedrock aquifers from the UBSDGB alluvial aquifer is included only for the modeled area because this area is underlain by the Denver Basin aquifer system. The UBSDGB in the unmodeled area directly overlies the Pierre Shale confining unit. The 2016 UBSDGB alluvial aquifer inflows and outflows for the modeled area, unmodeled area, and the net flows for modeled and unmodeled areas combined are displayed in figures 7,8 , and 9 , respectively.

\section{Evapotranspiration}

Evapotranspiration from the UBSDGB alluvial aquifer in the modeled area as computed by ZONEBUDGET for 2016 was $-8,450 \mathrm{ac}-\mathrm{ft}$ ( $-0.48 \mathrm{in} / \mathrm{yr})$ (table 3). Evapotranspiration from the UBSDGB alluvial aquifer in the unmodeled area estimated from the results of the modeled area for 2016 was $-3,206$ ac- $\mathrm{ft}(-0.54$ $\mathrm{in} / \mathrm{yr}$ ) (table 3). Combining the modeled and unmodeled evapotranspiration leads to a total evapotranspiration of $-11,656 \mathrm{ac}-\mathrm{ft}$ $(-0.50 \mathrm{in} / \mathrm{yr})$ from the UBSDGB alluvial aquifer (table 3$)$. Net recharge (precipitation and irrigation return flows minus evaporation) into the UBSDGB alluvial aquifer was negative with groundwater being removed from the UBSDGB alluvial aquifer over the total area of the basin. Combining the total inflow from recharge to the UBSDGB alluvial aquifer of 11,153 ac-ft and the total evapotranspiration of $-11,656$ ac-ft from the UBSDGB alluvial aquifer (table 3 ) results in a net recharge from UBSDGB alluvial aquifer of $-503 \mathrm{ac}-\mathrm{ft}$ ( $-0.02 \mathrm{in} / \mathrm{yr}$ ) (fig.9).

\section{Pumping Wells}

Pumpage from the UBSDGB alluvial aquifer in the modeled area as computed by ZONEBUDGET for 2016 was $-2,096$ ac-ft (-0.12 in/yr) (table 3$)$. A total of 137 pumping wells were
Table 5. Pumpage volumes for the 11 Town of Limon, Colorado, municipal pumping wells for 2016.

[Dave Stone, Town of Limon Town Manager, written commun., July 12, 2017]

\begin{tabular}{clc}
\hline $\begin{array}{c}\text { Well } \\
\text { name }\end{array}$ & $\begin{array}{c}\text { Aquifer in which } \\
\text { well is completed }\end{array}$ & $\begin{array}{c}\text { Total pumping } \\
\text { volume in 2016 } \\
\text { (acre-feet) }\end{array}$ \\
\hline C2 & Alluvial aquifer & -30.6 \\
C7 & Alluvial aquifer & -67.1 \\
M1 & Alluvial aquifer & -77.3 \\
M2 & Alluvial aquifer & 0.00 \\
P1 & Alluvial aquifer & -420 \\
P3 & Alluvial aquifer & -9.79 \\
P4 & Alluvial aquifer & -125 \\
S2 & Alluvial aquifer & 0 \\
B1\&2 & Alluvial aquifer & 0 \\
GC2 & Alluvial aquifer & -59.1 \\
GC3 & Alluvial aquifer & -20.2 \\
& & Total \\
\hline
\end{tabular}

screened in the alluvial aquifer in the unmodeled area of the UBSDGB for 2016 of which 11 municipal wells had actual reported pumpage volumes (table 5); the remaining well pumpage volume (table 6) was estimated using the values in table 1. Pumpage from the UBSDGB alluvial aquifer in the unmodeled area estimated from available pumpage data from the Colorado Division of Water Resources well-permit database (Colorado Division of Water Resources, 2017c) and Town of Limon (table 5) (Dave Stone, Town of Limon Town Manager, written commun., July 12,2017$)$ for 2016 was $-1,639$ ac-ft $(-0.28 \mathrm{in} / \mathrm{yr})$ (table 6). Combining the modeled and unmodeled well pumpage leads to a total well pumpage volume of $-3,735$ ac- $\mathrm{ft}(-0.16$ in/yr) from the UBSDGB alluvial aquifer (table 3).

\section{Outflow to Streams}

Outflow to streams from the UBSDGB alluvial aquifer in the modeled area as computed by ZONEBUDGET for 2016 was $-740 \mathrm{ac}-\mathrm{ft}(-0.04 \mathrm{in} / \mathrm{yr}$ ) (table 3). Outflow to streams from the UBSDGB alluvial aquifer in the unmodeled area estimated from results for the modeled area for 2016 was $-330 \mathrm{ac}-\mathrm{ft}(-0.06 \mathrm{in} / \mathrm{yr})$ (table 3$)$. Combining the modeled and unmodeled outflow to streams leads to a total outflow to streams of $-1,070 \mathrm{ac}-\mathrm{ft}(-0.05 \mathrm{in} / \mathrm{yr})$ from the UBSDGB alluvial aquifer (table 3 ). The net groundwater flow to the stream network in the basin was negative with flow discharging from the UBSDGB alluvial aquifer into streams. Combining the total inflow from streams of $38 \mathrm{ac}-\mathrm{ft}$ and the total outflow to streams of $-1,070 \mathrm{ac}-\mathrm{ft}$ for the UBSDGB alluvial aquifer (table 3 ) results in a net flow to streams from UBSDGB alluvial aquifer of $-1,032 \mathrm{ac}-\mathrm{ft}$ $(-0.04 \mathrm{in} / \mathrm{yr})$ (fig. 9$)$. 
Table 6. Total pumpage volume estimates for pumping wells in the unmodeled area in the Upper Big Sandy Designated Groundwater Basin, Colorado.

[Modified from table B1 in Paschke (2011)]

\begin{tabular}{|c|c|c|c|c|}
\hline $\begin{array}{l}\text { Well } \\
\text { use }\end{array}$ & $\begin{array}{l}\text { Aquifer in which } \\
\text { well is completed }\end{array}$ & $\begin{array}{c}\text { Pumping rate } \\
\text { (acre-feet per year) }\end{array}$ & $\begin{array}{c}\text { Number of } \\
\text { pumping wells }\end{array}$ & $\begin{array}{l}\text { Total pumping volume } \\
\text { (acre-feet) }\end{array}$ \\
\hline Municipal & Alluvial aquifer & -45.0 & 11 & $-809^{1}$ \\
\hline Irrigation & Alluvial aquifer & -41.0 & 17 & -697 \\
\hline Commercial or industrial & Alluvial aquifer & -9.0 & 8 & -72 \\
\hline Domestic and livestock & Alluvial aquifer & -0.6 & 101 & -61 \\
\hline \multirow[t]{2}{*}{ Household only } & Alluvial aquifer & -0.3 & 0 & 0 \\
\hline & & Total & 137 & $-1,639$ \\
\hline
\end{tabular}

${ }^{1}$ From table 5.

\section{Outflow to Adjacent Alluvial Aquifers}

Groundwater outflow from UBSDGB alluvial aquifer to the adjacent alluvial aquifers in the modeled area as computed by ZONEBUDGET for 2016 was -162 ac-ft $(-0.01 \mathrm{in} / \mathrm{yr})$ (table 3$)$. Outflow to adjacent alluvial aquifers in the unmodeled area was $-30 \mathrm{ac}-\mathrm{ft}(-0.01 \mathrm{in} / \mathrm{yr}$ ) (table 3$)$, which was computed from the results for the modeled area for 2016. Combining the modeled and unmodeled outflow to adjacent aquifers results in a total outflow to adjacent alluvial aquifers of $-192 \mathrm{ac}-\mathrm{ft}(-0.01 \mathrm{in} / \mathrm{yr})$ for the UBSDGB alluvial aquifer (table 3 ). The net flow between the adjacent alluvial aquifers and the UBSDGB alluvial aquifer was positive with flow entering the UBSDGB alluvial aquifer from the adjacent alluvial aquifers; therefore, this component of the water budget is discussed further in the "Inflow from Adjacent Alluvial Aquifers" section.

\section{Outflow to Underlying Bedrock Aquifers}

Groundwater outflow to the bedrock aquifers from the UBSDGB alluvial aquifer in the modeled area as computed by ZONEBUDGET for 2016 was -348 ac-ft ( $-0.02 \mathrm{in} / \mathrm{yr}$ ) (table 3). The net flow between the bedrock aquifers and the UBSDGB alluvial aquifer as computed by ZONEBUDGET for 2016 was positive with flow entering the UBSDGB alluvial aquifer from the bedrock aquifers; therefore, this component of the water budget is discussed further in the "Inflow from Underlying Bedrock Aquifers" section.

\section{Outflow to Downgradient Areas from the Upper Big Sandy Designated Groundwater Basin}

The net groundwater flow out of the UBSDGB was negative with flow leaving the basin at the downgradient end of the UBSDGB alluvial aquifer. In 2016, the groundwater outflow from the upgradient modeled area to the downgradient unmodeled area as calculated by
ZONEBUDGET was -303 ac-ft (-0.02 in/yr) (table 3). This modeled area outflow component was considered the same as the unmodeled area inflow component from the upgradient modeled area (table 3). Downgradient outflow from the unmodeled area was estimated to be $-2,300 \mathrm{ac}-\mathrm{ft}$ $(-0.39 \mathrm{in} / \mathrm{yr})$ in 2016 (Martin and Wood Water Consultants, Inc., 2009) (table 3). Combining the modeled and unmodeled outflow from the UBSDGB alluvial aquifer results in a total outflow from the basin of $-2,603 \mathrm{ac}-\mathrm{ft}(-0.11 \mathrm{in} / \mathrm{yr})$ (table 3).Combining the total area inflow to the basin from upgradient areas of $303 \mathrm{ac}-\mathrm{ft}$ and the total area outflow from the basin of $-2,603 \mathrm{ac}-\mathrm{ft}$ for the UBSDGB alluvial aquifer (table 3 ) results in a net groundwater flow out of the basin of $-2,300 \mathrm{ac}-\mathrm{ft}(-0.10 \mathrm{in} / \mathrm{yr})$ (fig.9).

\section{Groundwater Storage}

The groundwater storage presented in this report is considered an independent variable of the water budget. This report therefore uses the convention that a positive storage value is an inflow to the annual groundwater budget from storage (water is removed from storage), and a negative storage value is an outflow from the annual groundwater budget (water is added to storage). In the annual groundwater budget for 2016 (table 3), groundwater storage in the UBSDGB alluvial aquifer system is removed because annual groundwater outflows from storage exceed groundwater inflows to storage; in other words, water is removed from storage to balance the annual water budget. In contrast, if storage were an outflow (represented by a negative number) in the annual groundwater budget, groundwater storage in the aquifer would be added because annual groundwater inflows would exceed groundwater outflows. The inflows and outflows presented below are for the 2016 calendar year for the UBSDGB alluvial aquifer and for 1880 through 2016 for the modeled area only. In 2016, combining the net flow from storage for the modeled area of $73 \mathrm{ac}-\mathrm{ft}$ and the inflow from storage for 
the unmodeled area of 2,025 ac-ft results in a net positive flow from storage entering the UBSDGB alluvial aquifer of 2,098 ac-ft. The net flow from storage can also be calculated by adding the inflows for the total area excluding storage of $17,506 \mathrm{ac}-\mathrm{ft}$ and the outflows for the total area of $-19,694 \mathrm{ac}-\mathrm{ft}$ in 2016 , which resulted in a deficit of 2,188 ac-ft in the annual water budget. Combining the deficit in the annual water budget of 2,188 ac-ft for the total area with the outflow to storage in the UBSDGB alluvial aquifer for the total area of $-90 \mathrm{ac}-\mathrm{ft}$ (computed by ZONEBUDGET for the modeled area) results in a deficit of 2,098 ac-ft; because of the deficit, 2,098 ac-ft was removed from aquifer storage to balance the UBSDGB alluvial aquifer budget (fig.9).

\section{Change in Water-Budget Components Over Time}

The interaction between the bedrock aquifers and the UBSDGB alluvial aquifer was of particular interest because it has not been previously quantified. The interaction between the bedrock aquifers and the UBSDGB alluvial aquifer in 2016 is presented in table 4 , and the way in which these interactions have changed over time, from ZONEBUDGET model results for the modeled area only, is displayed in figure 11. From 1880 to 1940 , no change occurred in the flow rates between the bedrock aquifers and the UBSDGB alluvial aquifer; therefore, the values were not included in the figure. Previous pumpage estimates made by Robson (1987) show a substantial well pumpage increase between 1958 and 1962. This phenomenon

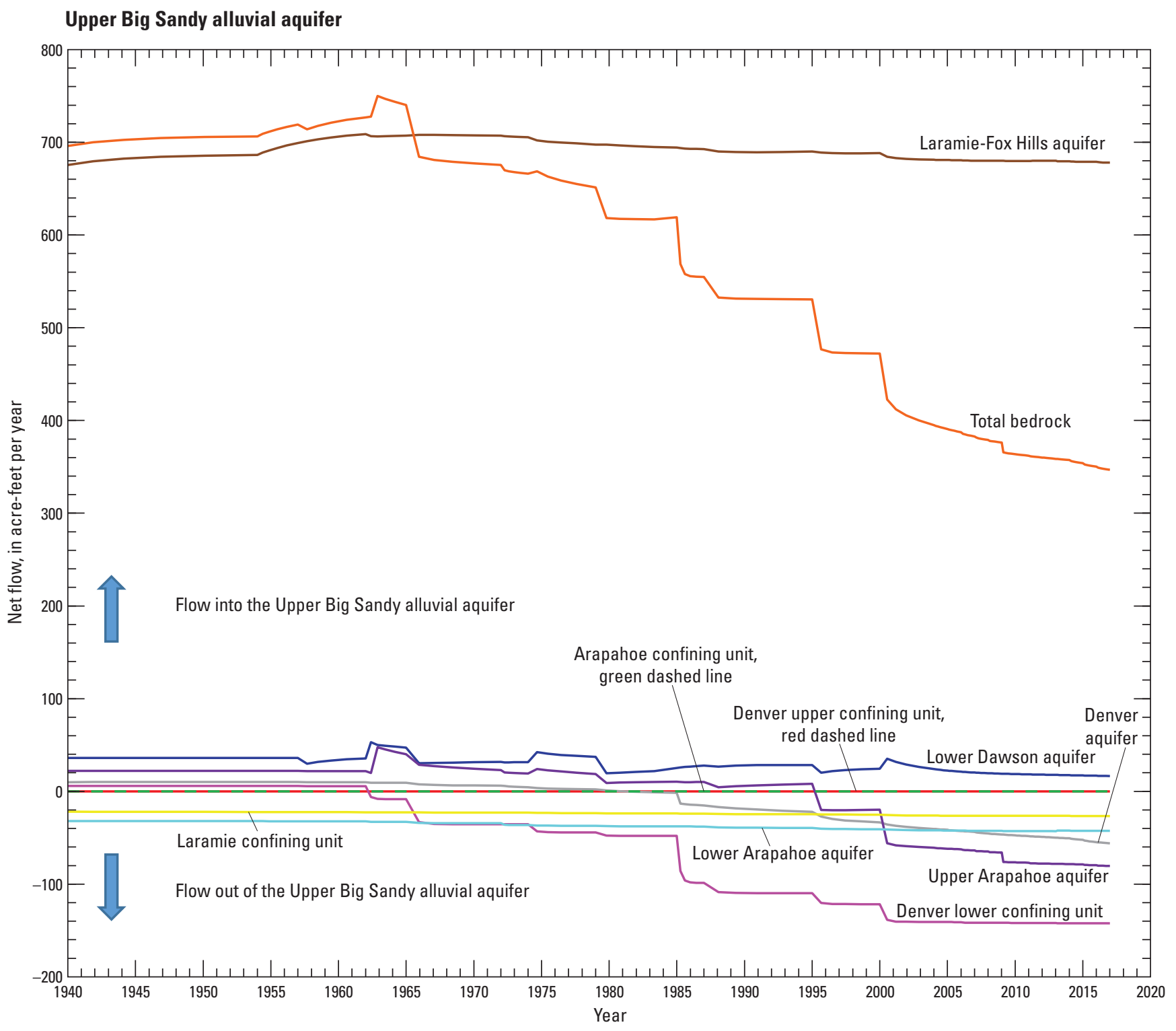

Figure 11. Change in flow rates over time between the bedrock aquifers and the Upper Big Sandy Designated Groundwater Basin alluvial aquifer. [When net flow is positive, flow is entering the Upper Big Sandy Designated Groundwater Basin alluvial aquifer, and when net flow is negative, flow is leaving the Upper Big Sandy Designated Groundwater Basin alluvial aquifer] 
seems to correspond with the point in time in figure 11 when noticeable change begins to occur in the flow rates between the bedrock aquifers and the UBSDGB alluvial aquifer. In figure 11 from 1958 through 2016, the most noticeable and on-going change in flow from the bedrock units occurred in the Denver lower confining unit, the upper Arapahoe aquifer, and the Denver aquifer; all three aquifers show a steady decrease over time in net flow to the UBSDGB alluvial aquifer. These results for the UBSDGB alluvial aquifer are consistent with results for the entire Denver Basin aquifer system (Paschke, 2011); increased pumping that began in 1958 in the Denver and upper Arapahoe aquifers has shifted the water budget such that these bedrock units have transitioned from being minor or non-contributors of inflow to the UBSDGB alluvial aquifer to being receivers of outflow from the UBSDGB alluvial aquifer. Although there are no pumping wells screened in the Denver lower confining unit, water is moving through the confining unit from the UBSDGB alluvial aquifer to the upper Arapahoe aquifer in response to pumping that occurs in the upper Arapahoe aquifer (Paschke, 2011). As a result, the total flow contribution from bedrock aquifers to the UBSDGB alluvial aquifer has declined steadily since the 1950s. Although this value has remained positive (net flow from the bedrock units into the UBSDGB alluvial aquifer) for 60 years, the flow has been reduced by more than 50 percent (fig. 11). The reduction in flow indicates that if no changes are made to the inflows to and (or) outflows from the UBSDGB alluvial aquifer, in another 60 years (2016-75), the net flow between the bedrock aquifers and the UBSDGB alluvial aquifer will become negative (net flow into the bedrock units from the UBSDGB alluvial aquifer).

The major inflows to and outflows from the UBSDGB alluvial aquifer over time were examined for the modeled area only (fig. 12). Groundwater flow into the UBSDGB alluvial aquifer from adjacent alluvial aquifers, groundwater outflow leaving the UBSDGB, and groundwater outflow to streams in the UBSDGB were static over time in the modeled area (fig. 12). Evapotranspiration and recharge from precipitation and irrigation return flows are climate-based components of the water budget and fluctuate on the basis of the climate from year to year. The last two components of the water budget, pumping wells and groundwater flow from underlying bedrock aquifers, are related. Finally, as a result of all the components in the water budget, storage can fluctuate between an inflow (water is removed from storage) and an outflow (water is added to storage) from one year to the

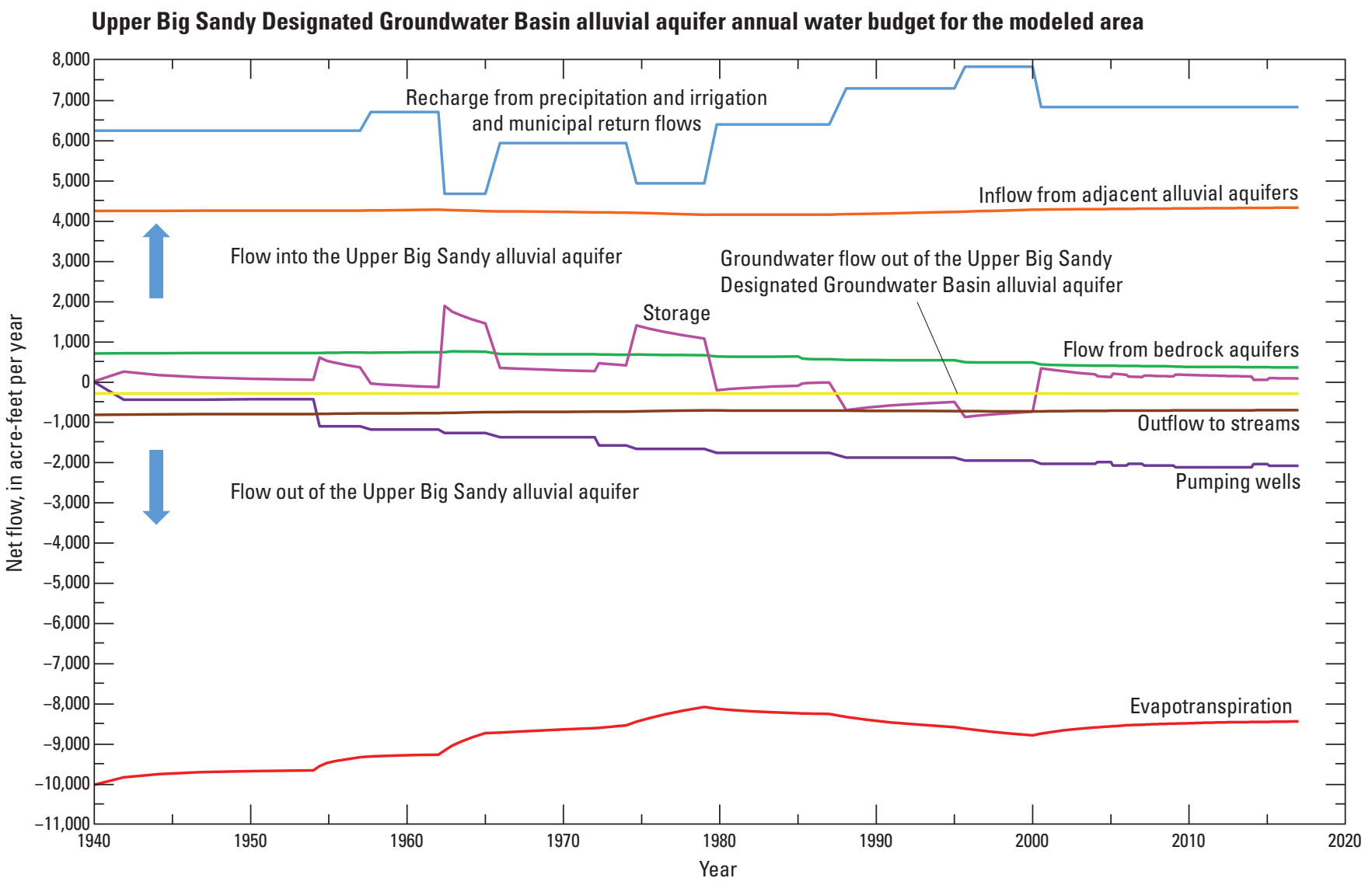

Figure 12. The annual water budget over time for the modeled area of the Upper Big Sandy Designated Groundwater Basin alluvial aquifer in Colorado. [When net flow is positive, flow is entering the Upper Big Sandy Designated Groundwater Basin alluvial aquifer, and when net flow is negative, flow is leaving the Upper Big Sandy Designated Groundwater Basin alluvial aquifer] 
next. Since 2000, storage has been an inflow to the water budget (fig. 12), which means that groundwater is being removed from the UBSDGB alluvial aquifer at a rate greater than the rate of recharge for the modeled area of the UBSDGB alluvial aquifer. This means that outflow from the modeled area exceeded inflow for the UBSDGB alluvial aquifer. Increased recharge from wetter than average years could increase the recharge and replenish the UBSDGB alluvial aquifer.

\section{Change in Groundwater Levels}

Groundwater levels over time provide useful data for interpreting temporal changes to storage in an aquifer system
(Paschke, 2011). Because the Denver Basin model was updated for the period 2004 through 2016, water levels from 2003 through 2016 are of particular interest to this study.

A query of the 2016 Colorado Division of Water Resources Groundwater Levels Report for the UBSDGB (Sares and Flor, 2016) identified 34 observation wells screened in the UBSDGB alluvial aquifer. Of those 34 observation wells, which are used solely for water-level observation, only 25 had data from 2003 through 2016. The groundwater-level change in the UBSDGB alluvial aquifer from 2003 through 2016 for each measured well is displayed in figure 13. From 2003 through 2016, 13 of the 25 observation wells had a decline in the groundwater-level elevation with an average

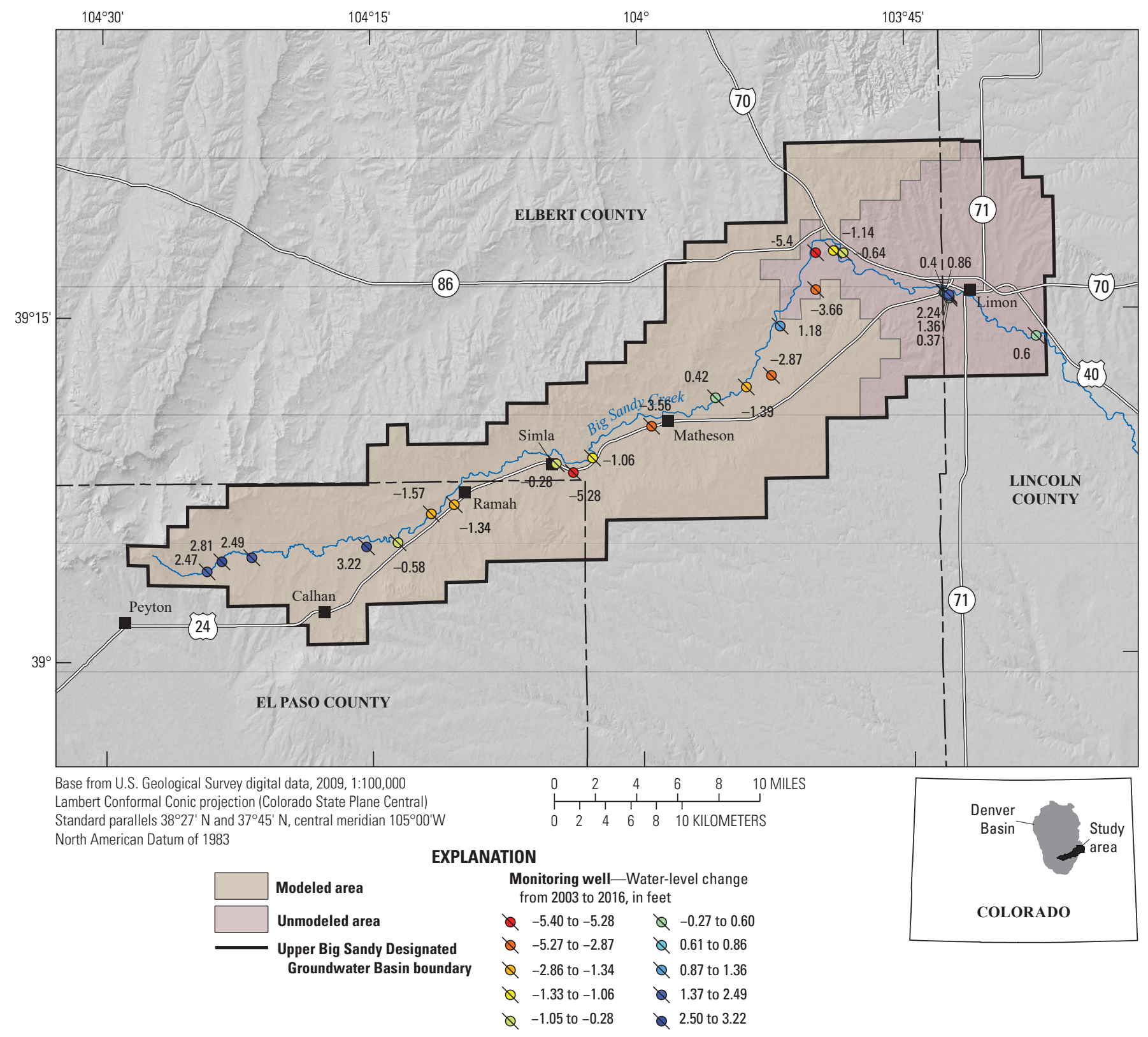

Figure 13. The change in groundwater levels in observation wells in the Upper Big Sandy Designated Groundwater Basin alluvial aquifer, Colorado, from 2003 through 2016. 
decline of -2.21 feet, and 12 of the 25 observation wells had an increase in the groundwater-level elevation with an average increase of 1.54 feet. From 2003 through 2016, in general, wells at the eastern and western edges of the UBSDGB had an increase in groundwater-level elevation, and the remaining wells had a decline. The areas with the least amount of recharge appear to coincide with the wells with negative groundwater-level change for the time period from 2003 through 2016 (fig. 10 and 13). The decline in groundwater levels shown in figure 13 also could be attributed to the negative bedrock flow in the central part of the UBSDGB alluvial aquifer (fig. 10). The western edge of the modeled area includes a number of wells that experienced a large increase in water level from 2003 through 2016. These wells occur in an area where the lower Dawson aquifer crops out beneath the UBSDGB alluvial aquifer (fig. 10), where the lower Dawson aquifer contributes inflow to the UBSDGB alluvial aquifer (fig. 11). The eastern edge of the modeled area has the greatest amount of flow from the bedrock aquifers to the UBSDGB alluvial aquifer (fig. 10). The eastern edge of the modeled area is underlain by the Laramie-Fox Hills aquifer (fig. 10) and is considered an area of regional groundwater discharge from the Laramie-Fox Hills aquifer (Paschke, 2011). The LaramieFox Hills aquifer is the largest contributor of bedrock aquifer inflow to the UBSDGB alluvial aquifer (fig. 11).

\section{Possible Future Work}

The results presented in this report are for currently (2016) available data. To improve upon these results, several pieces of additional data would be beneficial. First, a database containing, at a minimum, quantitative pumpage data, by aquifer, from high-capacity wells (municipal and irrigation wells) in the Upper Big Sandy Groundwater Management District could be developed. Currently (2016), no records are kept of pumpage from high-capacity wells. Ultimately, low-capacity wells (commercial or industrial, domestic, and household wells) would be included in estimates of pumpage from the UBSDGB. Second, observation wells spatially distributed across the UBSDGB would provide a quantitative way to monitor water-level changes. Third, the seasonal and temporal changes in groundwater levels can be accurately quantified only when observation wells are monitored several times a year instead of annually, which is how data are currently (2016) collected. Finally, a local, basin-specific model of the UBSDGB alluvial aquifer would provide a more detailed water budget for the UBSDGB than the current method of using a regional model for part of the study area and extrapolating those results to unmodeled parts of the UBSDGB. A basin-specific model could serve as a basin management tool for modeling changes in groundwater levels and storage under various future groundwater recharge and withdrawal scenarios.

\section{Summary}

The U.S. Geological Survey in cooperation with the Colorado Water Conservation Board and the Upper Big Sandy Groundwater Management District carried out a study in 2016 to evaluate potential groundwater storage changes within the Upper Big Sandy Designated Groundwater Basin (UBSDGB) alluvial aquifer, including groundwater flow between the UBSDGB alluvial aquifer and the Denver Basin bedrock aquifers. The UBSDGB alluvial aquifer is along the ephemeral Big Sandy Creek on the east-central edge of the Denver Basin aquifer system and covers an area of about 66,560 acres within the UBSDGB. The UBSDGB alluvial aquifer consists of unconsolidated Quaternary sand and gravel deposits that contain an unconfined (water table) groundwater system. The western three-fourths of the UBSDGB alluvial aquifer overlies the Tertiary and Cretaceous bedrock formations that compose the Denver Basin aquifer system. Because of its position with respect to the Denver Basin aquifer system, the western part (329 square miles) of the UBSDGB was included in the Denver Basin model (modeled area), whereas the eastern part (111 square miles) of the UBSDGB was not included in the Denver Basin model (unmodeled area).

The updated water budget for the UBSDGB alluvial aquifer, including annual change in groundwater storage in 2016, was determined by combining water-budget information from an existing Denver Basin model for about three-fourths of the study area with best estimates for the major waterbudget components for the area outside the Denver Basin aquifer system. The budget components for both parts of the UBSDGB, the modeled area and the unmodeled area, were estimated separately then were combined for an overall waterbudget estimate. The water-budget components were first estimated for the modeled area using outputs from the Denver Basin model. A basin-specific water budget for the UBSDGB alluvial aquifer from the Denver Basin model was computed using a modeling tool called ZONEBUDGET. The inflow components of the modeled area of the UBSDGB alluvial aquifer estimated using ZONEBUDGET were (1) recharge from precipitation and irrigation return flows, (2) inflow from streams, (3) groundwater inflow from adjacent alluvial aquifers, (4) groundwater inflow from underlying bedrock aquifers, and (5) inflow from storage. Because the western extent of the UBSDGB begins at the headwaters of the Big Sandy Creek at a topographic divide, there is no groundwater inflow from upgradient areas external to the UBSDGB. Because no urban land-use areas are delineated in the modeled area of the UBSDGB, the recharge inflow component includes only precipitation and return flows from agriculture irrigation (irrigation return flows) for this study. The outflow components of the modeled part of the UBSDGB alluvial aquifer estimated using ZONEBUDGET were (1) evapotranspiration, (2) pumping wells, (3) groundwater outflow to streams, (4) groundwater outflow to adjacent alluvial aquifers, (5) groundwater outflow to underlying bedrock aquifers, (6) groundwater outflow leaving the upgradient modeled area and entering the unmodeled 
area, and (7) outflow to storage. Based on the other inflow and outflow component calculations for the UBSDGB alluvial aquifer, ZONEBUDGET calculated an estimate of the inflow and outflow components to storage. The results from the Denver Basin model and ZONEBUDGET estimates were then extrapolated to the unmodeled area. The inflow components of the UBSDGB alluvial aquifer estimated for the unmodeled area were (1) recharge from precipitation and irrigation return flows, (2) inflow from streams, (3) groundwater inflow from adjacent alluvial aquifers, and (4) groundwater inflow from the upgradient modeled area. There was no flow to the UBSDGB alluvial aquifer from underlying bedrock aquifers for the unmodeled area because the UBSDGB alluvial aquifer in the unmodeled area is underlain by the Cretaceous Pierre Shale. The outflow components of the UBSDGB alluvial aquifer for the unmodeled area were (1) evapotranspiration, (2) pumping wells, (3) groundwater outflow to streams, (4) groundwater outflow to adjacent alluvial aquifers, and (5) groundwater outflow to downgradient areas from the UBSDGB.

The net groundwater flow into the basin from adjacent alluvial aquifers was positive with flow entering the UBSDGB alluvial aquifer. Combining the total inflow from adjacent alluvial aquifers of 5,317 ac-ft and the total outflow to adjacent alluvial aquifers of $-192 \mathrm{ac}-\mathrm{ft}$ for the UBSDGB alluvial aquifer results in a net flow from adjacent alluvial aquifers to UBSDGB alluvial aquifer of 5,125 ac-ft. The net flow between the underlying bedrock aquifers and the UBSDGB alluvial aquifer was positive with flow entering the UBSDGB alluvial aquifer from the bedrock aquifers. The net flow from the UBSDGB bedrock aquifers to UBSDGB alluvial aquifer as computed by ZONEBUDGET for 2016 was $347 \mathrm{ac}-\mathrm{ft}$. Combining the net flow from storage for the modeled area of $73 \mathrm{ac}-\mathrm{ft}$ and the inflow from storage for the unmodeled area of 2,025 ac- $\mathrm{ft}$ results in a net positive flow from storage entering the UBSDGB alluvial aquifer for the basin of 2,098 ac-ft.

Net recharge (precipitation and irrigation return flows minus evaporation) into the UBSDGB alluvial aquifer was negative with groundwater being removed from the UBSDGB alluvial aquifer over the total area of the basin. Combining the total inflow from recharge to the UBSDGB alluvial aquifer of $11,153 \mathrm{ac}-\mathrm{ft}$ and the total evapotranspiration of $-11,656 \mathrm{ac}-\mathrm{ft}$ from the UBSDGB alluvial aquifer results in a net recharge from UBSDGB alluvial aquifer of -503 ac-ft. Combining the modeled and unmodeled well pumpage led to a total well pumpage volume of $-3,735$ ac-ft from the UBSDGB alluvial aquifer. The net groundwater flow to the stream network in the basin was negative with flow discharging from the UBSDGB alluvial aquifer into streams. Combining the total inflow from streams of $38 \mathrm{ac}-\mathrm{ft}$ and the total outflow to streams of $-1,070 \mathrm{ac}-\mathrm{ft}$ for the UBSDGB alluvial aquifer results in a net flow to streams from UBSDGB alluvial aquifer of $-1,032 \mathrm{ac}-\mathrm{ft}$. The net groundwater flow out of the UBSDGB was negative with flow leaving the UBSDGB alluvial aquifer out of the basin. Combining the total area inflow to the basin from upgradient areas of $303 \mathrm{ac}-\mathrm{ft}$ and the total area outflow from the basin of $-2,603 \mathrm{ac}-\mathrm{ft}$ for the UBSDGB alluvial aquifer results in a net flow out of the basin of $-2,300 \mathrm{ac}-\mathrm{ft}$. In the annual groundwater budget for 2016, groundwater storage in the UBSDGB alluvial aquifer system was removed because annual groundwater outflows from storage exceeded groundwater inflows to storage; in other words, water was removed from storage to balance the annual water budget.

Increased pumping since 1958 in the Denver and upper Arapahoe aquifers, not necessarily in just the UBSDGB, has shifted the water budget such that these bedrock units have transitioned from being minor or non-contributors of inflow to the UBSDGB alluvial aquifer to being receivers of outflow from the UBSDGB alluvial aquifer. Since 2000, storage has been an inflow to the water budget, which means that outflow from the modeled area exceeded inflow for the UBSDGB alluvial aquifer. Increased recharge from wetter than average years could replenish the UBSDGB alluvial aquifer. From 2003 through 2016, 13 of the 25 observation wells screened in the UBSDGB alluvial aquifer had a decline in the groundwaterlevel elevation with an average decline of -2.21 feet, and 12 of the 25 observation wells had an increase in the groundwaterlevel elevation with an average increase of 1.54 feet. In general, wells at the eastern and western edges of the UBSDGB had an increase in groundwater-level elevation that appears related to areas of groundwater discharge from the lower Dawson and Laramie-Fox Hills bedrock aquifers to the UBSDGB alluvial aquifer. The remaining wells exhibited water-level declines. Future work could include the development of a basin-specific model to serve as a basin management tool for modeling changes in groundwater levels and storage under various future groundwater recharge and withdrawal scenarios.

\section{References Cited}

Anderson, M.P., and Woessner, W.W., 1992, Applied groundwater modeling: San Diego, Calif., Academic Press, Inc., $381 \mathrm{p}$.

Banta, E.R., Paschke, S.S., and Litke, D.W., 2017, MODFLOW2000 model used to simulate the groundwater flow of the Denver Basin Aquifer System, Colorado: U.S. Geological Survey data release, accessed August 17, 2017, at https://doi.org/10.5066/F77W69PQ.

Colorado Division of Water Resources, 2017a, Designated Groundwater Basins, accessed December 22, 2017, at http:// water.state.co.us/groundwater/cgwc/Pages/default.aspx.

Colorado Division of Water Resources, 2017b, Groundwater levels in the Upper Big Sandy Designated Ground Water Basin: Colorado Division of Water Resources, DWR_3071013, $23 \mathrm{p}$.

Colorado Division of Water Resources, 2017c, Well Permit Database, accessed September 22, 2017, at http:// www.dwr.state.co.us/WellPermitSearch/default.aspx. 
Doesken, N.J., Pielke, R.A., Sr., and Bliss, O.A.P., 2003, Climate of Colorado, Climatography of the United States No. 60: Fort Collins, Colo., Colorado Climate Center, Atmospheric Science Department, Colorado State University, accessed August 17, 2017, at http://ccc.atmos. colostate.edu/pdfs/climateofcoloradoNo.60.pdf.

Graham, Glenn, and VanSlyke, George, 2004, Development of the regulatory framework for Denver Basin aquifers: The Mountain Geologist, v. 41, no. 4, p. 153-160.

Harbaugh, A.W., 1990, A computer program for calculating subregional water budgets using results from the U.S. Geological Survey modular three-dimensional ground-water flow model: U.S. Geological Survey Open-File Report 90-392, 46 p., accessed September 17, 2017, at https:// pubs.er.usgs.gov/publication/ofr90392.

Harbaugh, A.W., Banta, E.R., Hill, M.C., and McDonald, M.G., 2000, MODFLOW-2000, the U.S. Geological Survey modular ground-water model-User guide to modularization concepts and the groundwater flow process: U.S. Geological Survey Open-File Report 2000-92, 121 p.

Kohn, M.S., 2018, MODFLOW2000 model and ZONEBUDGET computer program used to simulate the Upper Big Sandy Designated Groundwater Basin alluvial aquifer, Elbert, El Paso, and Lincoln Counties, Colorado, 2016: U.S. Geological Survey data release, https://doi.org/10.5066/P9DEOYGZ.

Martin and Wood Water Consultants, Inc., 2009, Upper Big Sandy Designated Ground Water Basin Phase 2 Water Balance Report, June 2009: Golden, Colo., Martin and Wood Water Consultants, Inc., 268 p.

Paschke, S.S. ed., 2011, Groundwater availability of the Denver Basin aquifer system, Colorado: U.S. Geological Survey Professional Paper 1770, 274 p.

Robson, S.G., 1983, Alluvial and bedrock aquifers of the Denver Basin-Eastern Colorado's dual groundwater resource: U.S. Geological Survey Water-Supply Paper 2302, 40 p.

Robson, S.G., 1987, Bedrock aquifers in the Denver Basin, Colorado-A quantitative water-resources appraisal: U.S. Geological Survey Professional Paper 1257, 73 p.

Sares, M.A., and Flor, A., 2016, Groundwater levels in the Upper Big Sandy Designated Ground Water Basin: Colorado Division of Water Resources Report, 28 p., accessed September 28, 2017, at http://dwrweblink. state.co.us/dwrweblink/0/doc/2907874/Electronic. aspx? searchid=7a0a8e79-415d-497c-b70d-8a669069d9eb.

Suburban Stats, 2017, Population demographics for Limon, Colorado, in 2016 and 2017, accessed August 25, 2017 at https://suburbanstats.org/population/colorado/how-manypeople-live-in-limon.
Upper Big Sandy Groundwater Management District, 2011, Rules, regulations and guidelines covering the conservation, management, utilization, preservation, protection, recharge, and administration of ground water located in the aquifers within the Upper Big Sandy Ground Water Management District in El Paso, Elbert, and Lincoln Counties, Colorado, accessed August 16, 2017, at http://water.state.co.us/ DWRIPub/Documents/UpperBigSandy.pdf.

Upper Big Sandy Groundwater Management District, 2018, Rules and Regulations: Upper Big Sandy Ground Water Management District, Calhan, Colo., accessed April 20, 2018, at http://upperbigsandygwmd.net/.

U.S. Department of Agriculture, 2012a, Census of agriculture 2012 county profile, Elbert County, Colorado, accessed August 25, 2017, at https://www.agcensus.usda.gov/ Publications/2012/Online_Resources/County_Profiles/ Colorado/cp08039.pdf.

U.S. Department of Agriculture, 2012b, Census of agriculture 2012 county profile, El Paso County, Colorado, accessed August 25, 2017, at https://www.agcensus.usda.gov/ Publications/2012/Online_Resources/County_Profiles/ Colorado/cp08041.pdf.

U.S. Department of Agriculture, 2017, Published cropspecific data layer, accessed September 22, 2017, at https:// nassgeodata.gmu.edu/CropScape/.

Publishing support provided by the Science Publishing Network, Denver and West Trenton Publishing Service Centers

For more information concerning the research in this report, contact the

Director, USGS Colorado Water Science Center

Box 25046, Mail Stop 415

Denver, CO 80225

(303) 236-4882

Or visit the Colorado Water Science Center website at https://co.water.usgs.gov/ 


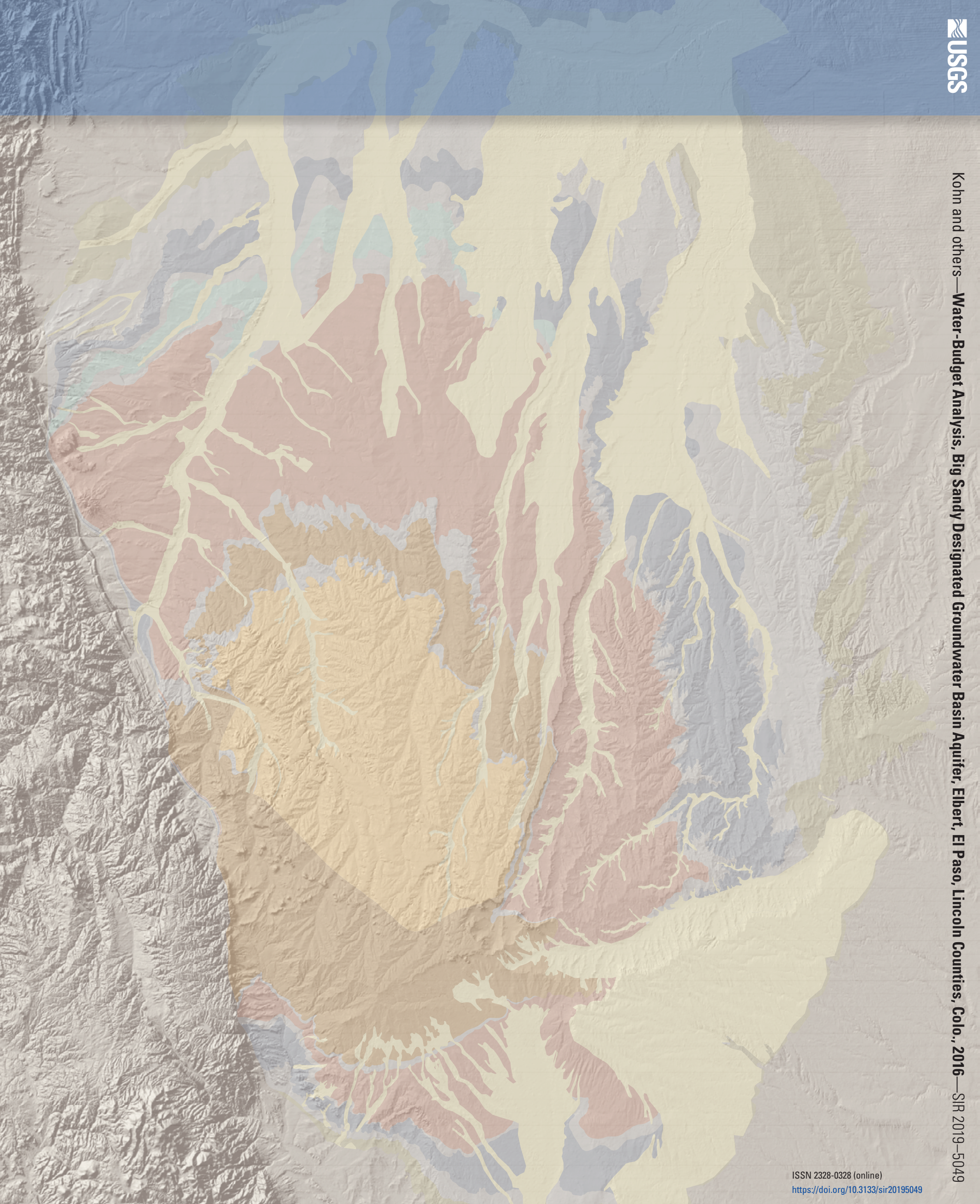

